\title{
Mycotoxin exposure and adverse reproductive health outcomes in Africa: a review
}

\author{
U.A. Eze ${ }^{1,2,3^{\prime \prime}}$, M.N. Routledge ${ }^{3}$, F.E. Okonofua ${ }^{4,5}$, J. Huntriss ${ }^{6}$ and Y.Y. Gong ${ }^{1,7}$ \\ ${ }^{1}$ School of Food Science and Nutrition, Food Science Building, University of Leeds, Woodhouse Ln, Leeds LS2 9JT, United \\ Kingdom; ${ }^{2}$ Department of Medical Laboratory Sciences, Faculty of Health Sciences, Ebonyi State University, P.M.B. 053, \\ Abakaliki, Nigeria; ${ }^{3}$ Leeds Institute of Cardiovascular and Metabolic Medicine, School of Medicine, University of Leeds, \\ Woodhouse Ln, Leeds LS2 9JT, United Kingdom; ${ }^{4}$ University of Medical Sciences, Ondo Medical Village, Laje Road, Ondo, \\ Nigeria; ${ }^{5}$ Centre of Excellence in Reproductive Health Innovation [CERHI], University of Benin, P.M.B 1154, Benin City, \\ Nigeria; ${ }^{6}$ Division of Reproduction and Early Development, Leeds Institute of Cardiovascular and Metabolic Medicine, \\ School of Medicine, University of Leeds, Woodhouse Ln, Leeds LS2 9JT, United Kingdom; ${ }^{7}$ Department of Food Safety Risk \\ Assessment, China National Center for Food Safety Risk Assessment, Ministry of Health, 7 Panjiayuan Nanli, Chaoyang \\ District, Beijing 100021, China P.R.; fsuae@leeds.ac.uk
}

Received: 19 October 2017 / Accepted: 7 May 2018

(c) 2018 Wageningen Academic Publishers



REVIEW ARTICLE

\begin{abstract}
It is well established that mycotoxin exposure can have adverse effects on reproductive health resulting to poor reproductive potential. The most studied mycotoxin in relation to poor reproductive health in humans is aflatoxin, although fumonisins, trichothecenes and zearalenone have also been reported to impair reproductive function and cause abnormal foetal development. These potent fungal toxins contaminate many food products making them a prominent agricultural, food safety and public health challenge, especially in Africa due to little or lack of mycotoxin regulation in agricultural products. Neonates can be exposed to aflatoxins in utero, as the toxins pass from mother to the foetus through the placenta. This exposure may continue during breast feeding, to the introduction of weaning foods, and then foods taken by adults. The consequences of aflatoxin exposure in mothers, foetus and children are many, including anaemia in pregnancy, low birth weight, interference with nutrient absorption, suppression of immune function, child growth retardation and abnormal liver function. In males, reports have indicated a possible relationship between aflatoxin exposure and poor sperm quality culminating in infertility. Maternal exposure to fumonisin during early pregnancy has been associated with increased risk of neural tube defects among newborns in regions where maize is the common dietary staple with the possibility of chronic fumonisin exposure. Furthermore, zearalenone has been linked to precocious puberty and premature thelarche in girls, correlating with extremely high serum oestrogen levels. This review presents an overview of the several reports linking aflatoxins, fumonisins, trichothecenes, and zearalenone exposure to poor reproductive health outcomes in Africa, with emphasis on birth outcomes, foetal health and infertility.
\end{abstract}

Keywords: endocrine disrupters, mycotoxins, neural tube defects, maternal and foetal health, infertility

\section{Introduction}

Mycotoxins contaminate many staple food crops and crops used in animal feed, particularly in sub-Saharan Africa and Asia. Several mycotoxins have been identified, however, those that are of public health significance include aflatoxins (AFs), ochratoxin A (OTA), fumonisins, zearalenone (ZEA) and deoxynivalenol (DON) due to their frequent occurrence in agricultural products and their adverse health effects in humans (Schatzmayer and Streit, 2013). Exposure tends to be highest in low income communities where food may be grown and stored locally, where there is a low diversity in diet and where socioeconomic deprivation contributes to malnutrition (Wild and Gong, 2010). A number of adverse health effects have been reported in various mycotoxins, with varying degrees of evidence. In regions where mycotoxin contamination of food is often high, there are often also high levels of reproductive health problems in 
humans, such as high rates of infertility, low birth weight, pre-term delivery, stillbirths and birth abnormalities (Agarwal et al., 2015; Mascarenhas et al., 2012; McClure et al., 2009; Ota et al., 2014). Causes of these reproductive health problems are multifactorial and undernutrition and poverty are major contributors. Nevertheless, the occurrence of chronic mycotoxin exposure in populations affected by high rates of such reproductive health problems has led to research into the possible role of mycotoxins as causes of these conditions. Most human research on the adverse reproductive health effects of mycotoxins has focused on AFs, fumonisins and ZEA, but there are also several animal and in vitro studies reporting reproductive toxicity and endocrine disrupting effects of other mycotoxins, including DON, OTA, nivalenol (NIV), and $\mathrm{T}-2$ toxin. However, this review is focused on the evidence that AFs, fumonisins, DON, NIV and ZEA contribute to a range of human reproductive health conditions, with aim of guiding future research and interventions designed to reduce harmful exposures to mycotoxins and reduce the risk of these adverse reproductive health outcomes.

\section{Aflatoxins}

AFs are major metabolites of Aspergillus flavus and Aspergillus parasiticus and are frequent contaminants of peanuts, maize, rice, and oil seeds, particularly in Africa and South Asia (IARC, 2002). The naturally occurring classes of AFs are aflatoxin $\mathrm{B}_{1}\left(\mathrm{AFB}_{1}\right)$, aflatoxin $\mathrm{B}_{2}\left(\mathrm{AFB}_{2}\right)$, aflatoxin $\mathrm{G}_{1}\left(\mathrm{AFG}_{1}\right)$ and aflatoxin $\mathrm{G}_{2}\left(\mathrm{AFG}_{2}\right)$, and the hydroxylation forms commonly found in milk and urine (aflatoxins $M_{1}$ and $\mathrm{M}_{2}\left(\mathrm{AFM}_{1}\right.$ and $\left.\mathrm{AFM}_{2}\right)$ ) (Kensler et al., 2011). $\mathrm{AFB}_{1}$ is the most toxic and is a major risk factor for hepatocellular carcinoma, particularly in individuals with chronic hepatitis $B$ virus infection. Acute toxicity causes liver failure and can be fatal. $\mathrm{AFB}_{1}$ has also been associated with growth impairment in children and modification of immune function (Wild et al., 2015). In addition, recent evidence indicates AFs may be involved in adverse reproductive health outcomes (Shuaib et al., 2010a; Smith et al., 2017a).

\section{Prevalence of aflatoxin exposure among pregnant women in Africa}

Due to the ubiquitous nature of AFs and their common contamination of food products, biomarkers of aflatoxin exposure have been detected in the blood of pregnant women and infant cord blood in different African countries. For example, Wild et al. (1991) assessed umbilical cord blood from neonates of 30 Gambian women, and found that $97 \%$ of maternal sera and $70 \%$ of cord sera were positive for the aflatoxin-albumin (AF-alb) adducts. AF-alb adducts were also detected in 119 out of 119 (100\%) maternal blood (range: $4.8-260.8 \mathrm{pg} / \mathrm{mg}$ albumin) and cord blood of 48 out of 99 (48.5\%) newborns (range: $5.0-89.6 \mathrm{pg} / \mathrm{mg}$ albumin) in The Gambia (Turner et al., 2007). In a subsequent study in
Ghana, AF-alb adducts (range: $0.44-268.73 \mathrm{pg} / \mathrm{mg}$ albumin) were detected in $100 \%$ of 755 pregnant women (Shuaib et al., 2010b). Another cross-sectional study showed that AFalb adducts were found in 34 of 98 (35\%) serum samples (range: $3.0-35.1 \mathrm{pg} / \mathrm{mg}$ albumin) and $\mathrm{AFM}_{1}$ (range: 4.1-408.6 $\mathrm{pg} / \mathrm{mg}$ creatinine) in 44 of 93 (48\%) urine samples taken from pregnant Egyptian women (Piekkola et al., 2012), whilst AF-alb adducts were detected in 100\% (99/99) of pregnant Gambian women (range: 4.8-521.6 pg/mg albumin during early pregnancy; 4.4-556.5 pg/mg albumin during later pregnancy) (Castelino et al., 2014). In a more recent study, urinary $\mathrm{AFM}_{1}$ was reported in $30 \%$ of 1,580 pregnant women in Zimbabwe (Smith et al., 2017b). Furthermore, De Vries et al., (1989) detected AFs in 37\% of 101 cord bloods in Kenya. AFs in cord blood have also been detected in 54.7\% of deliveries in United Arab Emirates, 37.8\% in Nigeria, 48\% in Thailand, $57 \%$ in Taiwan and 34\% in Ghana (reviewed in Shuaib et al., 2010a). The high prevalence of AFs and $\mathrm{AF}$-alb adducts in cord blood is an indication that $\mathrm{AFB}_{1}$ crosses the placental barrier reaching the foetal circulation (Denning et al., 1990; Wild et al., 1991).

\section{Determinants of aflatoxin exposure during pregnancy in Africa}

Several authors have reported the major determinants of AF exposure in pregnancy among African women. In a study in Ghana, pregnant women with higher economic status and low parity were $30-40 \%$ less likely to have high AFalb adducts in their blood (Shuaib et al., 2012). Economic status is a major driving factor of AF exposure in Africa as those with low economic status are more likely to consume foods that are prone to AF contamination (e.g. maize and groundnuts) and possibly, take unremoved mouldy foods (Jolly et al., 2006; Leroy et al., 2015; Shuaib et al., 2012). However, geographical location, seasonality and dietary practices were significant determinants of AF exposure among pregnant women in Zimbabwe as determined by urinary $\mathrm{AFM}_{1}$ (Smith et al., 2017b). In a study in Gambia, we found that seasonal differences affected AF-alb adduct levels in Gambian pregnant women with high levels occurring during the dry season and women in their late pregnancy also had higher AF-alb adducts compared to those in early pregnancy (Castelino et al., 2014). Subsequent study suggest participants' ethnicity, village of residence and the number of individuals in the household as significant predictors of high AF-alb adduct levels in Ghanaian general population (Jolly et al., 2006). The number of individuals in a household in most cases determines the quality of food consumed in Africa and high household numbers could predispose to the consumption of low quality foods which may be contaminated with mycotoxins (Jolly et al., 2006). In contrast, there was a significant correlation between blood AF-lysine adduct in adult Kenyan women and poverty level (Leroy et al., 2015). Notwithstanding the country and exposure biomarker applied, it is generally 
accepted that geographical location, season and calendar year, socio-economic status, pre-and post-harvest practices, and household dietary practices are major determinants of AFs exposure in pregnancy (Smith et al., 2017b).

\section{Maternal aflatoxin exposure and adverse pregnancy outcomes}

AF exposure in pregnant women is mostly due to ingestion of contaminated diets, and has been suggested to contribute to poor maternal, neonatal and child health, especially in Africa and Asia (Shuaib et al., 2010a). The consequences of AF exposure in mothers, neonates and children are many and they include anaemia in pregnancy, intrauterine growth restriction and low birth weight, interference with nutrient absorption, suppression of immune function, child growth retardation and abnormal liver function (Wild et al., 2015).

\section{Aflatoxin exposure during pregnancy, intrauterine growth restriction and low birth weight}

Maternal AF exposure during pregnancy has been associated with intrauterine growth restriction and low birth weight, anaemia in pregnancy, neonatal jaundice, and growth faltering in early childhood in Africa (Table 1). Studies evaluating aflatoxin exposure through the presence of AFs or metabolites in serum $\left(\mathrm{AFB}_{1}, \mathrm{AFB}_{2}, \mathrm{AFG}_{1}\right.$ and $\left.\mathrm{AFG}_{2}\right)$ or milk $\left(\mathrm{AFM}_{1}\right.$ and $\left.\mathrm{AFM}_{2}\right)$, instead of validated $\mathrm{AF}$ exposure biomarkers (urinary AFM 1 and $\mathrm{AFB}_{1}-\mathrm{N} 7$-guanine adduct or serum AF-alb adduct), reported associations between exposure and low birth weight (De Vries et al., 1989), stillbirth (Lamplugh et al., 1988) and neonatal jaundice (Ahmed et al., 1995; Abulu et al., 1997). In The Gambia, AF-alb adduct levels during pregnancy were associated with lower height-for-age $(-0.207 z$ scores, $P=0.044)$ and lower weight-for-age $(-0.249 z$ scores, $P=0.012)$ in infants during the first year of life (Turner et al., 2007). Shuaib et al. (2010c) also reported that of 755 pregnant Ghanaian women, those in the highest quartile of AF-alb (AF-alb: $>11.34 \mathrm{pg} / \mathrm{mg}$ albumin) were more likely to have babies with low birth weight (odds ratio (OR) 2.09; 95\% confidence interval (CI) 1.19-3.68) compared to the lowest quartile (AF-alb: $\leq 2.67$ $\mathrm{pg} / \mathrm{mg}$ albumin). Mycotoxin exposure biomarkers have advantages over exposure assessments through food and/or foodstuff as they provide more objective data on mycotoxins exposure, and correct for heterogeneous distribution of the mycotoxins in food. Validated biomarkers of AF exposure are biomarkers shown in epidemiological studies to be quantitatively associated with dietary AF intake and include urinary $\mathrm{AFM}_{1}$ and $\mathrm{AFB}_{1}$-N7-guanine adduct as well as serum AF-alb adduct (Kensler et al., 2011). Urinary AFM and $\mathrm{AFB}_{1}$-N7-guanine adduct reflect $\mathrm{AF}$ exposure in the previous 24-48 h while serum AF-alb adduct identifies AF exposure over the previous 2-3 months, and are therefore applied to detect short-term and long-term exposure, respectively. Several reports have shown a significant correlation between serum AF-alb adduct and urinary AFM 1 levels (Chen et al., 2018; Jolly et al., 2006; Piekkola et al., 2012) and therefore, reports involving these biomarkers should be accepted with confidence.

One postulated mechanism by which AF exposure could impact on growth is through interference with the insulinlike growth factor (IGF) axis. In Kenyan children exposed to AFs in utero, reduced IGF1 mRNA and protein levels were observed (Castelino et al., 2015). In vitro exposure of human hepatocyte cell line 16 (HHL-16) to $\mathrm{AFB}_{1}$ also significantly decreased IGF1 mRNA and protein expression (Castelino et al., 2015). Furthermore, differential DNA methylation of fibroblast growth factor-12 (FGF12) and insulin growth factor 1 receptor (IGF1R) genes were observed in the white blood cells from Gambian infants whose mothers were exposed to AFs during early pregnancy (Hernandez-Vargas et al., 2015). IGF1 and IGF1R genes are mediators of the growth hormone and plays major roles in embryonic development, foetal and post-natal growth (Baker et al., 1993). It has been reported that serum IGF1 levels are significantly reduced in infants with intrauterine growth restriction compared to controls (Leger et al., 1996). Although these studies provide an insight into the negative effects of AFs on the IGF1 axis leading to perinatal and neonatal growth restriction and low birth weight, these mechanisms remain unclear and needs to be further explored to demonstrate causal association. As $\mathrm{AFB}_{1}$ is known to cross the placental barrier, it is also possible that foetal cytochrome (CYP) 3A7 bioactivates $\mathrm{AFB}_{1}$ to the toxic $\mathrm{AFB}_{1}-8$, 9-epoxide after placental transfer of $\mathrm{AFB}_{1}$ from maternal blood during pregnancy resulting in foetal toxicity (Partanen et al., 2010).

\section{Aflatoxin exposure in pregnancy and maternal anaemia}

Anaemia in pregnancy is one of the leading causes of maternal mortality during child birth in Africa and Asia (Khan et al., 2006; IFPRI, 2016). Recent studies assessing AF-alb adduct levels in pregnant women in Ghana reported significant association between AF exposure and anaemia in pregnancy as well as low birth weight. Shuaib et al. (2010b) reported that AF-alb level was associated with anaemia in pregnancy with the odds of being anaemic increasing by $21 \%(\mathrm{OR}, 1.21, P=0.01)$ and each quartile of AF-alb reaching an $85 \%$ increased odds in the highest quartile (AF-alb: $>11.34 \mathrm{pg} / \mathrm{mg}$ albumin) compared to the low quartile (AFalb: $\leq 2.67 \mathrm{pg} / \mathrm{mg}$ albumin) group (OR, 1.85; CI, 1.16-2.95).

Experimental studies have shown that AF promotes the haemolysis of erythrocytes, inhibits haematopoiesis, impairs iron absorption, affects haemoglobin levels and induces microcytic hypochromic anaemia in multiple animal species (Andretta et al., 2012; Eisa and Metwally, 2011; Kumar and Balachandran, 2005; Lanza et al., 1978; Verma and Raval, 1991; Yousef et al., 2003). It has also been hypothesised that 
Table 1. Human studies on mycotoxins exposure, reproductive and developmental toxicity. ${ }^{1}$

\author{
References \\ Study design and location \\ Mycotoxin levels detected \\ De Vries et al., 1989 \\ A cross-sectional study of AFs were detected in $53 \%$ of maternal blood \\ 125 mother-infant pairs in samples and in $37 \%$ of cord samples. \\ Kenya. \\ Maternal blood: AFB 1 (89-11,574 pg/ml); \\ AFM $_{1} / A / M_{2}(12-1,689 \mathrm{pg} / \mathrm{ml})$. Cord blood: \\ AFB $_{1}(86-6,819 \mathrm{pg} / \mathrm{ml}) ;$ AFM $_{1} / \mathrm{AFM}_{2}$ (17-656 \\ $\mathrm{pg} / \mathrm{ml})$.
}

Outcome

Comments

Turner et al., 2007

Maternal and cord blood was collected from 138 singleton infants followed for 14 months in The Gambia.

Shuaib et al., $2010 \mathrm{c}$

Blood from 755 pregnant Ghanaian women.

Lamplugh et al., 1988

Blood samples from 188 cord bloods and 264 breast milk samples from Ghana and 77 motherinfants pairs from Nigeria with maternal and cord blood.

Maxwell et al., 1994

A cross-sectional study to evaluate the effect of AFs and napthols exposure on birth weight of 625 babies at delivery in Ibadan, Nigeria.
AF-alb adducts detected by ELISA and 119 (100\%) maternal blood, $48(48.5 \%)$ cord blood and 13 blood samples (11\%) from week 16 children had detectable AF-alb adducts. Maternal: 23.3-64.1 pg/mg albumin (mean: $38.9 \mathrm{pg} / \mathrm{mg}$ albumin); Cord: $2.5-7.9 \mathrm{pg} / \mathrm{mg}$ albumin (mean: $2.5 \mathrm{mg} / \mathrm{mg}$ albumin).

Blood AF-lysine adduct detected by HPLC and all the blood samples had detectable AF-lysine adduct (range: $0.44-268.73 \mathrm{pg} / \mathrm{mg}$ albumin; Mean: $10.9 \pm 19.00 \mathrm{pg} / \mathrm{mg}$ albumin).

No correlation between AF levels in maternal and cord blood. Female infants born to mothers exposed high levels AF had significantly lower birth weight compared to those from mothers with nondetectable blood AF.

Higher AF-alb levels in maternal blood (at 5 and 8 months of pregnancy) were associated with lower HAZ (-0.207 SD; $P=0.044)$ and WAZ $(-0.247$ $\mathrm{SD} ; P=0.012)$ scores in children during the first year of life. Maternal AF-alb in pregnancy was not associated with infant weight or length at birth.

Pregnant women with AF-lysine in the highest quartile $(>11.34$ $\mathrm{pg} / \mathrm{mg}$ ) were 2.09 times more likely to have low birthweight infants (95\% Cl: 1.19-3.68).

Blood AF-lysine adduct detected by HPLC and all the blood samples had detectable AF-lysine adduct (range: $0.44-268.73 \mathrm{pg} / \mathrm{mg}$ albumin; Mean: $10.9 \pm 19.00 \mathrm{pg} / \mathrm{mg}$ albumin). $30.3 \%$ had anaemia.

Very high blood AF-lysine adduct was significantly associated with the odds of being anaemic (OR: 1.85 ; $\mathrm{Cl}$ : 1.16-2.95).

AFs detected in 64 (34\%) cord bloods and $90(34 \%)$ breast milk from Ghana, and 16 maternal $(21 \%)$ and $9(12 \%)$ cord blood from Nigeria. Ghana cord: AFB 1 (185-43 ng/l); $\mathrm{AFB}_{2}(11-925 \mathrm{ng} / \mathrm{l}) ; \mathrm{AFM}_{1}(34-7,320 \mathrm{ng} / \mathrm{l})$; $\left.\mathrm{AFM}_{2}(30-572 \mathrm{ng} / \mathrm{l}) ; \mathrm{AFG}_{1} 354-1,354 \mathrm{ng} / \mathrm{l}\right)$, $\mathrm{AFG}_{2}$ (37 ng/l); AFL (117 ng/l). Ghana breast milk: $\mathrm{AFB}_{1}(130-8,218 \mathrm{ng} / \mathrm{l}) ; \mathrm{AFB}_{2}(49-50$ ng/l); AFL (64-270 ng/l); AFM 1 (20-1,816 ng/l); $\mathrm{AFM}_{2}(16-2,075 \mathrm{ng} / \mathrm{l})$. Nigeria maternal blood: $\mathrm{AFB}_{1}(540-10,390 \mathrm{ng} / \mathrm{l}) ; \mathrm{AFB}_{2}(28-33 \mathrm{ng} / \mathrm{l})$; $\mathrm{AFM}_{1}(38-483 \mathrm{ng} / \mathrm{l}) ; \mathrm{AFM}_{2}(48-3,480 \mathrm{ng} / \mathrm{l})$. Nigeria cord blood: AFB $_{2}(0-10 \mathrm{ng} / \mathrm{l}) ; \mathrm{AFM}_{1}$ (25-8,942 ng/l); AFM $_{2}(208-378$ ng/l)

AFs were found in $91(14.6 \%)$ of the cord bloods. The distributions and levels were: AFB $_{1}(168-69,973 \mathrm{ng} / \mathrm{ml}) ;$ AFB $_{2}$ (15-144 ng/ $\mathrm{ml}) ;$ AFM $_{1}(32-11,354 \mathrm{ng} / \mathrm{ml}) ;$ AFM $_{2}(14-3,644$ $\mathrm{ng} / \mathrm{ml})$.
AF occurrence and concentration was detected more in the rainy season than in dry season. Presence of $\mathrm{AF}$ biomeasures in cord blood confirmed AF crosses placental barrier to the foetus.
In utero AF and napthols exposure did not correlate with birth weight at delivery. levels.

AF occurrence in maternal and cord blood was significantly higher in the rainy season than in the dry season. Stillbirths occurred in mother and cord bloods with high AFs

There was seasonal variation in maternal AF-alb levels. Maternal AF-alb levels was significantly higher in blood samples collected in December - March compared to samples collected in either April - November $(P<0.001)$.

Other parameters showed a trend towards an increased risk $\left(P_{\text {trend }}=0.007\right)$.

The odds of being anaemic was stronger in pregnant women after exclusion of those with malaria, intestinal parasitic infection or low folate level. AF exposure in pregnancy was associated with anaemia.

One stillbirth was recorded from a mother from high AFs exposure level $\left(\mathrm{AFB}_{1}: 553\right.$ $\mathrm{ng} / \mathrm{ll}$. 
Table 1. Continued.

\begin{tabular}{|c|c|}
\hline References & Mycotoxin levels detected \\
\hline \multicolumn{2}{|l|}{ Study design and location } \\
\hline \multicolumn{2}{|l|}{ Ibeh et al., 1994} \\
\hline $\begin{array}{l}\text { Case-control study to } \\
\text { determine the association } \\
\text { of AFs exposure and male } \\
\text { infertility using } 50 \text { infertile } \\
\text { males and } 50 \text { fertile } \\
\text { controls from Benin City, } \\
\text { Nigeria. }\end{array}$ & $\begin{array}{l}\text { The mean AF concentrations was } 1.660 \pm 0.04 \\
\mu \mathrm{g} / \mathrm{ml} \text { in infertile men and } 1.041 \pm 0.01 \mu \mathrm{g} / \\
\mathrm{ml} \text { in the fertile control group). Aflatoxins } \\
\text { were detected in } 40 \% \text { of the infertile men } \\
\text { compared to } 8 \% \text { in Fertile controls. }\end{array}$ \\
\hline \multicolumn{2}{|l|}{ Uriah et al., 2001} \\
\hline $\begin{array}{l}\text { A case-control study to } \\
\text { examine the association } \\
\text { between aflatoxin } \\
\text { exposure and human } \\
\text { reproduction in Benin City, } \\
\text { Nigeria using } 30 \text { infertile } \\
\text { males and } 25 \text { fertile } \\
\text { controls. }\end{array}$ & $\begin{array}{l}\text { Serum and semen } \mathrm{AFB}_{1} \text { concentrations } \\
\text { ranged from } 700-1,392 \mathrm{ng} / \mathrm{ml} \text { and } 60-148 \\
\text { ng/ml, respectively in infertile males with } \\
\text { values significantly higher than those in the } \\
\text { fertile group. One semen sample with no live } \\
\text { spermatozoa (azoospermia) had an } \mathrm{AFB}_{1} \\
\text { levels as high as } 1,450 \mathrm{ng} / \mathrm{ml} \text {. Approximately } \\
37 \% \text { of semen and blood of infertile men had } \\
\text { detectable aflatoxins than the controls. }\end{array}$ \\
\hline
\end{tabular}

Mohammed et al., 2014

A case-control hospitalbased study that examined the AFs concentration in semen samples from $108(60$ infertile men and 48 fertile controls) visiting Sohag University Hospital, Egypt.

Szuets et al., 1997

Study on young girls with early thelarche/ mastopathy in Southern Hungary.

Massart et al., 2008

Study on serum samples of 32 girls with CPP and 31 female healthy female controls from North-West Tuscany, Italy.

Bandera et al., 2011

A cross-sectional study to determine the association between the exposure of ZEA and its metabolites on body size and breast development in 163 girls from New Jersey, USA.

Tomaszewski et al., 1998

\section{Endometrial tissue} specimens collected from 49 women (endometrial adenocarcinoma $n=27$, endometrial hyperplasia $\mathrm{n}=11$, normal proliferative endometrium $n=11$ ).

Outcome

Comments

AF exposure was associated with increased sperm abnormality.

AF exposure suggested as a contributory factor to male infertility in Nigeria.
$\mathrm{AFB}_{1}$ was present in $25 \%$ of the semen of infertile patients, compared to $2.1 \%$ among the controls $(P=0.0007)$.

\section{ZEA was detected in the serum of 5 out of 36 early patients with concentrations ranging from $18.9-103 \mu \mathrm{g} / \mathrm{ml}$.}

ZEA (723.5-1,143.9 pg/ml) and a-ZOL (104.5$108.5 \mathrm{pg} / \mathrm{ml}$ ) were detected from the serum of 6 of the 32 girls with CPP. All the controls had no detectable mycotoxins.

$78.5 \%$ of the girls had detectable levels of ZEA and its metabolites (ZEA: $0.05-33.12 \mathrm{ng} / \mathrm{ml}$; a-ZOL: 0.003-10.69 ng/ml).

ZEA suspected to have antioestrogenic effect. as a potential contributor to idiopathic infertility in males.

ZEA reported to be associated with early thelarche/ mastopathy.

ZEA suspected of inducing central maturation of the hypothalamic-pituitarygonadal axis causing CPP in exposed girls.

The concentration of ZEA in 3 endometrial hyperplasia samples was $47.8 \pm 6.5 \mathrm{ng} / \mathrm{ml}$ and $167.0 \pm 17.7 \mathrm{ng} / \mathrm{ml}$ in 22 adenocarcinoma samples. associated with hyperplastic and neoplastic endometrium.
ZEA suspected to be
Higher percentage of sperm abnormality $(50.0 \%)$ was found in infertile males with high exposure to AFs compared to the fertile control group (10.0-15.0\%).

\section{AFs exposure caused} decreased sperm concentration and increased sperm abnormalities.

Severe reduction in sperm count, reduced motility, high percentage of sperm with abnormal morphology, and high viscosity in the semen of the infertile group $(P<0.05)$ compared to the fertile group.

\section{Childhood ZEA exposure was associated with early breast development in young girls.}

Mycotoxin positive patients had higher height, weight and height velocity compared to those who had no mycotoxin detected in their serum.

\section{Girls exposed to ZEA and its} metabolites presented with shortness and had late-onset of breast development.

Normal endometrial samples had no detectable concentration of ZEA. Also 8 hyperplastic and 5 neoplastic endometrial samples had no detectable concentration of ZEA.

\footnotetext{
${ }^{1} \mathrm{AF}=$ aflatoxin; $\mathrm{AF}-$ alb = aflatoxin-albumin; $\mathrm{AFL}=$ aflatoxicol; $\mathrm{AFs}=\mathrm{AFB}_{1}, \mathrm{AFB}_{2}, \mathrm{AFM}_{1}, \mathrm{AFM}, \mathrm{AFG}_{1}$ and $\mathrm{AFG}_{2} ; \mathrm{Cl}=$ confidence interval; $\mathrm{CPP}=\mathrm{central}$ precocious puberty; ELISA = enzyme-linked immunosorbent assay; $\mathrm{HAZ}$ = height-for-age Z-score; HPLC = high performance liquid chromatography; OR = odd ratio; $\mathrm{SD}=$ standard deviation; $\mathrm{WAZ}$ = weight-for-height Z-score; ZEA = zearalenone; $\mathrm{a}-\mathrm{ZOL}=\mathrm{a}$-Zearalenol.
} 
aflatoxin could cause anaemia by impairing iron absorption and bioavailability as well as inhibition of erythropoiesis (Smith et al., 2017a). To date, no human research has been performed to test this hypothesis.

\section{Aflatoxin exposure and male infertility}

Male infertility is increasing in both developed and developing countries (Mascarenhas et al., 2012). The prevalence of male infertility varies between developed countries with USA standing at 6\% (Chandra et al., 2013) whereas it is higher in UK at 10-15\% (Oakley et al., 2008). In sub-Saharan Africa, infertility prevalence rates are higher and range from 20-35\% (Etuk, 2009). The infertility belt' stretching from West Africa, through Central to East Africa are known geographical regions with high infertility prevalence in Africa (Etuk, 2009). Our previous case control study has pointed to environmental and foodborne contaminants (e.g. pesticides, phthalates, bisphenol A, mycotoxins, cadmium, lead, arsenic, and caffeine) as possible causes of male infertility in Africa (Okonofua et al., 2005), but the exact contaminants have yet to be identified. Subsequently, we have argued for further research to uncover the role of food contaminants, such as AFs in the rising incidence and prevalence of male infertility in the African region (Eze and Okonofua, 2015) as these toxins are major contaminants of local foods consumed in the region. Although preliminary experiments have identified possible roles for AFs in the causation of infertility in the animal models (Agnes and Akbarsha, 2003; Ahmed et al., 2012; Ortatatli et al., 2002; Supriya et al., 2014), this is yet to be confirmed in humans, where little research is available.

There are a few human studies reporting the potential of AF exposure in causing male infertility in Africa (Table 1). In Nigeria, Ibeh et al. (1994) examined the presence of AFs in the semen of 100 adult males consisting of 50 infertile men and 50 fertile men to ascertain if there is a relationship between AFs and male infertility. Among the 50 semen samples from the infertile group, $20(40 \%)$ had detectable level of AFs and $50 \%$ of the semen samples had sperm with abnormalities in sperm count, morphology and motility whereas only 4 ( $8 \%$ ) of the fertile males had AFs in their semen with $10-15 \%$ of the semen showing sperm abnormalities. In addition, the concentrations of AFs found in the semen of infertile males were higher than fertile males. When adult male albino rats were fed with animal feed contaminated with $8.5 \mu \mathrm{g} \mathrm{AFB} / \mathrm{g}$ feed for 14 days, they had decreased sperm count, abnormal morphology, reduced motility and viability (Ibeh et al., 1994). In an in vitro study, AFs also significantly reduced the motility of sperm cells (Ibeh et al., 2000). In a casecontrol study involving 30 infertile and 25 fertile males, Uriah et al. (2001) found significantly higher levels of $\mathrm{AFB}_{1}$ in the blood (700-1,392 ng/ml) and semen (60-48 $\mathrm{ng} / \mathrm{ml}$ ) of the infertile men compared to the fertile men.
A case-control hospital-based study that examined the AF concentrations in semen samples from 108 men (60 infertile men and 48 fertile controls) visiting a University Hospital in Egypt has also been reported (Mohammed et al. 2014). It was observed that $\mathrm{AFB}_{1}$ was present in $25 \%$ of the semen of infertile patients, compared to $2.1 \%$ found in fertile controls $(P=0.0007)$. Among the infertile patients with $\mathrm{AFB}_{1}$ exposure, severe reduction in sperm count, reduced sperm motility, high percentage of sperm with abnormal morphology, and high viscosity in the semen were evident compared to the fertile group with low detectable $\mathrm{AFB}_{1}$ (Mohammed et al., 2014).

The negative effects of $\mathrm{AFB}_{1}$ on sperm parameters could be attributed to its ability to interfere with the biosynthesis of androgens and alteration of testicular function resulting to the inhibition of spermatogenesis and sperm maturation giving rise to the production of abnormal sperm cells (Adedara et al., 2014; Agnes and Akbarsha, 2003; Ahmed et al., 2012; Picha et al., 1986; Supriya et al., 2014). For instance, in adult male roosters fed with diets containing $\mathrm{AFB}_{1}(5,10$ and $20 \mathrm{mg} / \mathrm{l})$ for 8 weeks, a suppression of spermatogenesis, abnormalities in sperm morphology and count, reduced plasma testosterone and testicular atrophy were observed compared to the control adult roosters (Ortatatli et al., 2002). In a more recent study, exposure of bull semen to $\mathrm{AFB}_{1}(0.1,1,10$ and $100 \mu \mathrm{M})$ in vitro for $4 \mathrm{~h}$ decreased sperm viability, caused hyper-polarisation of the sperm mitochondrial membrane and negatively affected sperm DNA integrity (Komsky-Elbaz et al., 2018).

\section{Fumonisins}

Fumonisins are primarily produced by Fusarium verticillioides (previously known as Fusarium moniliforme) and Fusarium proliferatum which contaminate maize and maize-based food products, although their presence in other agricultural products (e.g. sorghum, cowpea, asparagus, rice and farro) has been occasionally reported (Bulder et al., 2012; Rheeder et al., 2016; Voss et al., 2006). Human exposure to fumonisin $\mathrm{B}_{1}\left(\mathrm{FB}_{1}\right), \mathrm{B}_{2}\left(\mathrm{FB}_{2}\right)$ and $\mathrm{B}_{3}$ $\left(\mathrm{FB}_{3}\right)$ is high in regions where home-grown maize are used as dietary staples (Gong et al., 2008; Van der Westhuizen et al., 2011). $\mathrm{FB}_{1}$ is the most common of the numerous fumonisin analogues and the most studied fumonisins, and has been classified as a possible human carcinogen (Group 2B) by the International Agency for Research on Cancer (IARC, 2002).

Consumption of $\mathrm{FB}_{1}$-contaminated maize and maizebased foods has been associated with high occurrence of oesophageal cancer in the former Transkei region of South Africa (Misihairabgwi et al., in press; Rheeder et al., 1992) and Linxian region of China (Sun et al., 2007). Similarly, in Mazandaran Province of Iran where there is also a high incidence of oesophageal cancer, increased concentrations 
of fumonisins have been detected in maize grown in the area (Alizadeh et al., 2012; Shephard et al., 2002; Yazdanapanah et al., 2006). In animals, $\mathrm{FB}_{1}$ has been linked to spontaneous equine leukoencephalomalacia (Marasas et al., 1988; Smith et al., 2002), porcine pulmonary oedema (Harrison et al., 1990; Hascheck et al., 2001), liver and kidney toxicity in different animal species (Bolger et al., 2001; Voss et al., 2001), and liver and kidney cancer in rodents (Gelderblom et al., 1991; Howard et al., 2001a,b).

\section{Fumonisin exposure, reproductive toxicity and birth defects}

Growth retardation, delayed or incomplete ossifications, cleft palate or hydrocephalus, and foetal death have also been found in pregnant animals fed with $\mathrm{FB}_{1}$-contaminated feeds (Voss and Riley, 2013). Studies evaluating the reproductive and developmental toxicity of $\mathrm{FB}_{1}$ in humans are very rare. However, consumption of $\mathrm{FB}_{1}$ contaminated feeds have been reported to impair the reproductive potential of Syrian hamsters (Floss et al., 1994), rabbits (Ewuola and Egbunike, 2010), rats (Flynn et al., 1996; Gbore et al., 2012) and chicken embryos (Bacon et al., 1995; Javed et al., 1993; Zacharias et al., 1996). Gbore and colleagues have performed several studies to examine how dietary $\mathrm{FB}_{1}$ exposure in piglets and boars affect their reproductive function and they observed that such exposure caused delay in puberty in piglets and impaired sperm production and semen quality of boars (Gbore and Egbunike, 2008; Gbore, 2009a,b).

In humans, fumonisins are reported to be environmental risk factor for birth defects, notably neural tube defects (NTDs). NTDs (spina bifida, exencephaly and craniorhachischisis or meningio-myeloceole) are foetal malformations occurring as a result of failure of the embryonic neural tubes to close properly during the early period of gestation (Voss and Riley, 2013; Voss et al., 2006). Maternal exposure to high concentrations of $\mathrm{FB}_{1}$ through the ingestion of contaminated maize and maizebased foods during early pregnancy has been associated with increased risk of NTDs among newborns in regions known to consume maize as staple foods (Hendricks, 1999; Marasas et al., 2004; Melnick and Marazita, 1998; Missmer et al., 2006). In the Transkei region of South Africa and Cameron County, Texas (USA) along the Texas-Mexico border, where maize is a dietary staple and where there is high chronic fumonisin exposure, there have been reports of high incidence of NTDs (Hendricks, 1999; Marasas et al., 2004; Missmer et al., 2006). The incidence of NTDs in these regions is known to be 6-10 times higher compared to the average NTDs incidence rate found globally $(\approx 10 / 10,000$ live births) (Gelineau-Van Waes et al., 2009; Hendricks, 1999; Marasas et al., 2004).
A high incidence of NTDs (27 per 10,000 live births) was observed in the newborns of Mexican-American women living along the Texas-Mexico border who conceived between 1990 and 1991 (Hendricks, 1999). As a result, Missmer et al. (2006) conducted a population-based casecontrol study among Mexican-American women who delivered newborns affected by NTDs between 1995 and 2000 to evaluate if maternal fumonisin exposure during pregnancy was associated with NTDs in neonates. In this study, Missmer and colleagues assessed serum sphinganine to sphingosine (Sa:So) ratio of 163 Mexican-American women with NTD-affected pregnancies and 189 MexicanAmerican women who delivered babies without NTDs within the study period. In addition, fumonisin levels were determined from 146 household corn tortillas and 114 tortillas obtained from grocery stores to estimate preconceptional dietary fumonisin exposure. The maternal serum Sa:So ratio ranged from 0.08 to 0.36 whereas fumonisin levels in tortillas ranged from non-detectable to $1,690 \mathrm{ng} / \mathrm{g}$. Moderate consumption of tortilla compared to low consumption during the first trimester of pregnancy was associated with increased OR with NTDs in newborns after adjusting for body mass index, serum $\mathrm{B}_{12}$ and folate, and date of conception (OR: 2.4; 95\% CI: 1.1-5.3). However, higher intakes of tortillas resulted to either a slight decrease in NTDs incidence or absence of NTDs. With regard to the maternal serum Sa:So ratio, higher levels of fumonisin exposure was associated with higher incidence of NTDs in newborns whereas those with the highest Sa:So ratio ( $>0.35$ ) had low incidence of NTDs in newborns. It was suggested that at the highest estimated dietary or maternal serum fumonisin exposure, miscarriages or stillbirth might have occurred resulting to low incidence of NTD in this group (Missmer et al., 2006). Worthy of note is that this study estimated fumonisin exposure by measuring $\mathrm{FB}_{1}$ in foodstuff which has previously failed to provide accurate data on human exposure due to heterogeneous distribution of mycotoxins in food (Shephard et al., 2007). In addition, Missmer et al. (2006) applied maternal serum Sa:So ratio as a biomarker of fumonisin exposure. Although serum and urinary Sa:So ratio is suggested as a useful biomarker of fumonisin exposure in animals (Van der Westhuizen et al., 2001), it failed to correlate with human dietary exposure to fumonisins (Van der Westhuizen et al., 2008, 2010). The method of fumonisin exposure assessment applied by Missmer et al. (2006) could have inaccurately estimated fumonisin exposure and results should be interpreted with caution. Therefore, future studies should apply urinary $\mathrm{FB}_{1}$ biomarker which has been shown to correlate well with human dietary fumonisin exposure (Gong et al., 2015; Shirima et al., 2013; Van der Westhuizen et al., 2011).

In animal studies, $\mathrm{FB}_{1}$ has been shown to induce NTDs in cultured mouse embryos (Sadler et al., 2002), and altered embryogenesis and caused NTDs development in foetus of pregnant mouse exposed during the early gestation 
(Gelineau-Van Waes et al., 2005). Although $\mathrm{FB}_{1}$ is suggested as an etiologic agent in the development of NTDs, other factors including genetics and maternal nutrition play an important role in pregnancy outcome and dietary folic acid supplementation prior and during pregnancy is known to reduce the occurrence of NTDs (Greene and Copp, 2005). The potential for $\mathrm{FB}_{1}$ to cause NTDs is primarily attributed to its structural similarity with sphingamine and sphingosine (Gelineau-Van Waes et al., 2005). FB 1 and other fumonisins competitively interfere with ceramide synthase which is involved in the de novo synthesis of complex glycosphingolipids resulting to the accumulation of sphingamine and sphingosine in tissues, serum and urine (Bolger et al., 2001; Merrill et al., 2001; Riley and Voss, 2006; Voss and Riley, 2005; Voss et al., 2006). It has been postulated that NTDs are induced by fumonisins as a result of decreased concentration of complex sphingolipids, disruption of lipid rafts and impairment in the function of the high affinity placental carriers (folate binding protein 1 in mice and folate receptor alpha in humans) involved in folate transport causing folate deficiency in the foetus during early pregnancy and failure of the foetal neural tube to close properly (Gelineau-Van Waes et al., 2005, 2009, 2012; Voss and Riley, 2013; Voss et al., 2001). In addition, the complex glycol-sphingolipids are important in the maintenance of cell membrane integrity, cell growth and migration, cell differentiation, cell morphology and endothelial cell permeability and therefore, disruption of sphingolipid metabolism by fumonisins can negatively affect embryonic morphogenesis and cell apoptosis (Merrill et al., 2001; Yahia and Kamata, 2017). Based on these studies discussed above, the negative impacts of $\mathrm{FB}_{1}$ on reproductive function in animal and in vitro models cannot be ignored as there is a homology in organ systems between animals and humans.

\section{Trichothecenes}

The trichothecenes are toxic sesquiterpenoid mycotoxins produced by Fusarium, Stachybotrys and Myrothecium species of fungi during their growth in food and/or the environment (Pestka, 2010a,b). The broad family of trichothecenes have been classified into four groups: types A, B, and D based on the substitution pattern of the tricyclic 12, 13 epoxytrichothec-9-ene core structure (Escrivá et al., 2015). Type A trichothecenes include T-2 toxin, HT-2 toxin, neosolaniol and diacetoxyscirpenol, whereas the type B group are fusarenon-X, NIV and DON and its 3-acetyl and 15-acetyl derivatives. The detailed toxicological effects and molecular mechanisms of trichothecenes toxicity has been reviewed in Pestka (2010a,b) and Escrivá et al. (2015).

\section{Reproductive and developmental health effects of deoxynivalenol exposure}

DON is one of the type B trichothecenes and is known to cause disruption of gastrointestinal permeability, impair growth hormone signalling, dysregulate the expression of genes involved in inflammatory response, immunotoxicity, haematological disorders, and alteration of the neuroendocrine responses in humans and animals (Pestka, 2010a,b). The molecular mechanisms underlying these pathological effects involve the causation of oxidative damage, induction of apoptosis and autophagy, alteration of membrane integrity, and inhibition of DNA, RNA and protein synthesis (Payros et al., 2016; Pestka, 2010b). The effects of DON on human reproduction and development are scarce, however, there is literature reporting its adverse effects on reproduction and development in animal and in vitro models (Yu et al., 2017a).

DON has been implicated in the disruption of oocyte maturation, embryo resorption and foetal malformation in mice (Hou et al., 2014; Khera et al., 1982, 1984; Yu et al., 2017b), rats (Collins et al., 2006), and swine (Alm et al., $2002,2006)$. In a study to assess the toxic effects of DON on mouse embryo, Khera et al. (1982) exposed pregnant mice in their gestation days (GD: 8-11) to DON $(0.5-25 \mathrm{mg} / \mathrm{kg} /$ body weight (bw)) through oral gavage. DON at $0.5 \mathrm{mg} /$ $\mathrm{kg} / \mathrm{bw}$ had no maternal and foetal toxicity, however, at 1 , 2.5 and $5 \mathrm{mg} / \mathrm{kg} / \mathrm{bw}$ DON caused foetal malformation. In addition, there was embryo resorptions in mice treated with 5,10 and $25 \mathrm{mg} / \mathrm{kg} / \mathrm{bw}$ whereas significant reduction in live foetuses were observed at $>5 \mathrm{mg} / \mathrm{kg} / \mathrm{bw}$. In a subsequent study, maternal toxicity, foetal malformation and embryo resorption were reported in mice and rats exposed to DON at $>1 \mathrm{mg} / \mathrm{kg} / \mathrm{bw}$ (Debouck et al., 2001; Khera et al., 1984). Similarly pregnant rabbits fed with DON contaminated diet showed $100 \%$ incidence of embryo resorption in the 1.8 -and $2.0 \mathrm{mg} / \mathrm{kg}$ groups and decreased mean foetal weight in the 1.0 and $1.6 \mathrm{mg} / \mathrm{kg}$ group (Khera et al., 1986). However, none of the doses caused foetal malformation or showed teratogenic potential. In accordance with the above results, Hou and colleagues found that exposure of mice with DON-contaminated maize $(3.875 \mathrm{mg} / \mathrm{kg} /$ diet) for 4 weeks resulted in poor oocyte indices and low developmental competence of the ovaries (Hou et al., 2014). Taken together, these studies indicate that a high exposure to DON during pregnancy could directly induce foetal malformation or indirectly affect embryonic and foetal development as a result of maternal toxicity (Collins et al., 2006). With regard to studies on rats treated orally with DON, the CONTAM Panel (EFSA, 2017a) sets the no-observed-adverse-effect-level as $1.0 \mathrm{mg} / \mathrm{kg}$ bw per day for reproductive endpoints, $1.0 \mathrm{mg} / \mathrm{kg}$ bw per day for foetal toxicity and $0.5 \mathrm{mg} / \mathrm{kg}$ bw per day for maternal toxicity. 
The toxicity of DON to male germ cell in animals have also been reported. For instance, exposure of mice to DON induced testicular germ cell degeneration, decreased absolute caudal epididymal sperm numbers, caused reduction in caudal epididymal weights, and reduced serum testosterone levels (Sprando et al., 1999, 2005). This is supported by an in vitro study in which exposure of MA-10 murine Leydig cell line to DON increased the release of reactive oxygen species, significantly reduced cell viability and caused significant decline in forskolin-induced progesterone secretion after 24 h of exposure (Savard et al., 2016). In a more recent study, we showed that DON was strongly cytotoxic to MA-10 cells after $48 \mathrm{~h}$ of exposure with concentrations as low as $29.63 \mathrm{ng} / \mathrm{ml}(0.1 \mu \mathrm{M})$ and $296.32 \mathrm{ng} / \mathrm{ml}(1 \mu \mathrm{M})$ showing significant cytotoxicity (Eze et al., 2018). Urinary concentrations of $436 \mathrm{ng} / \mathrm{ml}(1.471 \mu \mathrm{M})$ and $1,238 \mathrm{ng} / \mathrm{ml}(4.178 \mu \mathrm{M})$ have been reported for DON and its conjugates in pregnant women (Sarkanj et al., 2013; Wells et al., 2016) and therefore, the concentrations causing cytotoxic effects on MA-10 cells have clinical relevance.

DON can be transferred through the placenta to the foetus in pregnant sows (Goyarts et al., 2007; Dänicke et al., 2007) and it is likely that human foetus will be exposed to DON during pregnancy. In an in vitro placental perfusion using BeWo cell line, Nielsen et al. (2011) showed that DON was transported across the membrane and caused a dose-dependent decrease in the secretion of beta-human chorionic gonadotrophin ( $\beta$-hCG). Normal $\beta$-hCG level is required for the proper functioning of the placenta and foetal development, therefore the reduction in this important hormone further supports the embryo resorption, foetal death and malformation reported in animal studies. In addition, it has been argued that DON exposure in females causes the accumulation of reactive oxygen species, induction of autophagy and apoptosis, and alteration of epigenetic modification in the female reproductive system resulting to DON-induced reproductive and developmental toxicity (Han et al., 2016; Yu et al., 2017b).

In summary, it is plausible that human exposure to DON either in utero or during post-natal period can impair reproduction and development. Therefore, a properly designed in vitro and in vivo bioassays as well as human epidemiological study is required to provide stronger evidence establishing the association between exposure to DON and adverse reproductive health outcomes in humans.

\section{Reproductive and developmental toxicity of nivalenol}

Similar to DON, the effects of NIV on reproduction and development have also been reported (Pestka, 2010a), although there is no literature on the reproductive health effects in human beings. Ito and colleagues reported that intraperitoneal administration of NIV $(0.1-1.5 \mathrm{mg} / \mathrm{kg} \mathrm{bw} /$ day) to pregnant ICR mice from 7-15 days of gestation caused vaginal bleeding in $60 \%$ of the exposed mice, stillbirths and induced 48-88\% embryo deaths, especially at 0.5 and $1.5 \mathrm{mg} / \mathrm{kg}$ bw (Ito et al., 1986). It was also observed that the injection of $3 \mathrm{mg} \mathrm{NIV} / \mathrm{kg}$ bw on gestation day 7 was highly toxic to both the embryo and placenta culminating in stillbirths within $48 \mathrm{~h}$. In a similar study, maternal and embryo toxicity which resulted to intrauterine growth retardation was reported when pregnant mice (GD: 7-15) were either fed with $6-30 \mathrm{mg} / \mathrm{kg} /$ diet of NIV or 1-20 mg/ $\mathrm{kg}$ bw of NIV by oral gavage, particularly at the highest doses (Ito et al., 1988). Teratogenic effects were not observed in any of the concentrations of NIV used either in contaminated feed or oral gavage (Ito et al., 1988). When female F344/DuCrj rats were fed diets containing NIV at $6.25,25$ and $100 \mathrm{mg} / \mathrm{kg}$ for 90 days, histopathological features showed increase in atretic ovarian follicles and interstitial glands, impaired corpora lutea development, and uterine atrophy with dioestrus endometrial mucosa change in those fed the highest dose $(100 \mathrm{mg} / \mathrm{kg})$ (Takahashi et al., 2008; Sugita-Konishi et al., 2008). However, there was no adverse effect on the primary and secondary follicles. On the other hand, there was no effect on the reproductive system in male F344/DuCrj rats fed with same diet containing the same amount of NIV (Takahashi et al., 2008; Sugita-Konishi et al., 2008). In contradiction to the above studies, pregnant sows fed with maize contaminated with NIV did not affect any reproductive parameters assessed (Williams and Blaney, 1994). It can be deduced that female rodents are more susceptible to NIV than their male counterparts and pigs.

\section{Zearalenone}

Zearalenone (ZEA) produced by Fusarium species is also considered as one of the common mycotoxins posing a threat to human and animal reproductive health (Zinedine et al., 2007). ZEA is primarily converted by hydroxysteroid hydrogenases to phase I metabolites, including $\alpha$-zearalenol $(\alpha$-ZOL), $\beta$-zearalenol ( $\beta$-ZOL), $\alpha$-zearalanol $(\alpha$-ZAL), $\beta$-zearalanol ( $\beta$-ZAL) and zearalanone (ZAN) (EFSA, $2017 b)$. ZEA and the metabolites are known endocrine disruptors due to their resemblance to $17 \beta$-oestradiol, enabling them to disrupt the binding of $17 \beta$-oestradiol to oestrogen receptors. Both in vivo and in vitro studies show that $\alpha$-ZOL has higher oestrogenic potency compared to ZEA, whereas $\beta$-ZOL has lower oestrogenic potency (EFSA, $2017 \mathrm{~b})$. It has been reported to cause hyper-oestrogenism with attendant reproductive disorders in farm animals (Zinedine et al., 2007). In animals, ZEA is known to reduce testosterone levels and induce abnormal sperm quality in males (Yang et al., 2007; Zatecka et al., 2014), and cause ovarian follicle atresia, uterine hyperplasia, and degeneration of oocyte meiotic chromatin in females (Alm et al., 2006; Obremski et al., 2003; Skorska-Wyszyńska et al., 2005; Yamini et al., 1997). Despite the evidence that ZEA causes adverse effects on reproduction in animals, 
there are currently no published reports of associations of ZEA with infertility or birth defects in human populations.

There have been some reports of the association of ZEA exposure with central precocious puberty (CPP), premature thelarche, and hyperplastic and neoplastic endometrium (Table 1). In a study comprising 32 girls with CPP and 31 healthy female controls, elevated levels of ZEA and $\alpha-Z O L$ were detected in the serum of six of the 32 cases (Massart et al., 2008, 2010). In response to a high incidence of CPP in the Viareggio region of North-West Tuscany in Italy, Massart et al. (2008) recruited 32 girls (17 from Viareggio region and 15 from Pisa) with idiopathic CPP visiting the Paediatric Endocrine Centre of Pisa and matched them with 31 healthy female controls. In these groups, ZEA and its metabolites were assessed and matched with height, weight and height velocity, body mass index, bone age, and gonadal secretion. Among the $17 \mathrm{CPP}$ patients from Viareggio region, 6 (35\%) had detectable levels of ZEA (mean: $933.7 \pm 200.3 \mathrm{pg} / \mathrm{ml}$ ) and $\alpha$-ZOL (mean: $106 \pm 1.9$ $\mathrm{pg} / \mathrm{ml}$ ) whereas none of the $15 \mathrm{CPP}$ patients from Pisa had ZEA or its metabolites detected in their serum. It was also observed that the six girls with ZEA and $\alpha$-ZOL exposure had higher height, weight and height velocity after 12-month triptorelin (gonadotrophin-releasing hormone agonist) treatment compared to the $26 \mathrm{CPP}$ patients and 31 healthy controls with non-detectable serum ZEA and $\alpha$-ZOL (Massart et al., 2008). As a result of these parameters, ZEA and $\alpha$-ZOL exposure were suggested as predisposing factors of idiopathic CPP in prepubertal girls. However, the ZEA and its metabolites could not be detected in the other 26 girls with CPP giving an inconclusive result and therefore, other environmental contaminants may have been predisposing factors of the reported CPP (Massart et al., 2008, 2010). Previously, ZEA exposure was also speculated to be associated with early breast development among young Hungarian girls (Szuets et al., 1997). In this report, five of 36 early telarche/mastopathy patients in the South-East Region of Hungary had high serum level of ZEA $(18.9-103.5 \mu \mathrm{g} / \mathrm{ml})$ and it was speculated that ZEA could be a contributory factor for the development of early telarche/ mastopathy (Szuets et al., 1997). However, this study could not clearly state statistically how the concentration of ZEA was related to early telarche/mastopathy development and so, should be interpreted with caution. Other studies also suggest that ZEA may be a contributory factor to premature thelarche and idiopathic CPP in prepubertal girls (Schoental, 1983; Deng et al., 2012; Asci et al., 2014). In contradiction to these studies above, Bandera and colleagues conducted a cross-sectional study comprising 163 girls (age: 9-10 years) from New Jersey in USA to evaluate the effects of exposure to ZEA and its metabolites on body size and breast development (Bandera et al., 2011). In this study, $78.5 \%$ of the girls had urinary ZEA (0.05-33.12 ng/ $\mathrm{ml}), \alpha-Z O L(0.003-10.69 \mathrm{ng} / \mathrm{ml}), \beta-Z O L(0.05-1.10 \mathrm{ng} /$ $\mathrm{ml}), \alpha-Z A L(0.02-0.57 \mathrm{ng} / \mathrm{ml}), \beta-Z A L(0.04-0.60 \mathrm{ng} / \mathrm{ml})$ and ZAN (0.07-3.31 ng/ml), with those who consumed beef and popcorn the day prior to urine collection having significantly higher concentrations compared to those who did not take these foods. Girls who had detectable levels of urinary ZEA and its metabolites had lower height and delayed onset of breast development after adjusting for age, body mass index, isoflavone intake, and recruitment year, and it was concluded that exposure to ZEA and its metabolites had anti-oestrogenic effects on the girls (Bandera et al., 2011). The difference in the results reported in this study compared to the previous studies could be attributed to the small sample size of ZEA exposure (5 or 6), detection of ZEA and metabolites in serum instead of urine, and having subjects comprising of girls undergoing CPP treatment (Bandera et al., 2011). Therefore, a welldesigned longitudinal studies with larger sample size, the inclusion of people with different ethnic background and countries, and the use of valid ZEA exposure biomarkers would certainly provide stronger evidence for establishing a causal association. In addition, reproductive hormones such as oestrogen, progesterone, follicle stimulating hormone, and luteinising hormone should be evaluated and included in the statistical analysis as they can also influence the onset of puberty in girls.

However, biologically relevant doses of ZEA (5-10 mg/kg bw) caused precocious puberty in immature female rats as a result of early induction of the hypothalamic kisspeptin (KISS1)-G-protein coupled receptor-54 (GPR54) signalling pathway which is responsible for the initiation of puberty onset, regulation of the hypothalamo-pituitary-gonad axis and reproductive function (Kriszt et al., 2015; Yang et al., 2016). The precocious puberty in treated rats were evidenced through the induction of Kiss1, GPR54 and GnRH (Gonadotropin-releasing hormone) expressions in the hypothalamus at both mRNA and protein levels (Yang et al., 2016). This could be the same mechanism through which ZEA causes precocious puberty in human beings since mutations and/or inactivation of the GPR54 and/or KISS1 genes in humans and mice (gpr54 and kiss1) has been linked to reproductive dysfunction, including delayed puberty onset, abnormal oestrus cycles and infertility (Kirilov et al., 2013; Semple et al., 2005).

\section{Mycotoxin co-exposure and implication for human reproductive health}

Multiple mycotoxin exposure biomarkers have been reported in several population studies which show that human beings are often simultaneously exposed to mixtures of mycotoxins (Table 2). For instance, in the former Transkei region of South Africa, Shephard and colleagues examined 53 urine samples and demonstrated that mixtures of biomarkers such as DON, ZEA, FB ${ }_{1}$ and OTA as well as their metabolites can be detected frequently in the human urine samples (Shephard et al., 2013). Similarly, out of 
Table 2. Summary of selected studies on human exposure to mycotoxin mixtures.

\begin{tabular}{|c|c|c|c|c|c|c|}
\hline eferences & ;ountry & No. & $\begin{array}{l}\text { Individuals } \\
\text { examined }\end{array}$ & $\begin{array}{l}\text { No of } \\
\text { positive } \\
\text { samples (\%) }\end{array}$ & $\begin{array}{l}\text { Mycotoxin exposure } \\
\text { biomarkers detected }\end{array}$ & Co-exposure in a single individual ${ }^{1}$ \\
\hline hn et al., 2010 & Korea $^{2}$ & 12 & $\begin{array}{l}11 \text { adults, } \\
1 \text { child }\end{array}$ & $12(100 \%)$ & $\mathrm{AFM}_{1}$, OTA & $\mathrm{AFM}_{1}, \mathrm{OTA}$ \\
\hline ubert et al., 2011 & Spain $^{2}$ & 27 & adults & not stated & $\mathrm{AFG}_{2}, \mathrm{OTA}, \mathrm{DON}$ & not stated \\
\hline Solfrizzo et al., 2011 & Italy ${ }^{2}$ & 10 & adults & $10(100 \%)$ & OTA, DON & DON, OTA \\
\hline Warth et al., 2012a & Austria $^{2}$ & 27 & adults & $26(96 \%)$ & $\begin{array}{l}\text { DON, DON-3-GIcA, DON- } \\
\text { 15-GICA }\end{array}$ & DON, DON-3-GIcA, DON-15-GlcA \\
\hline Narth et al., 2012b & Cameroon $^{2}$ & 175 & $\begin{array}{l}145 \text { HIV-positive } \\
\text { adults, } \\
30 \text { HIV-negative } \\
\text { adults }\end{array}$ & $110(63 \%)$ & $\begin{array}{l}\text { AFM }_{1}, \text { OTA, } \text { FB }_{1}, \mathrm{FB}_{2} \\
\text { DON, DON-3-GIcA, } \\
\text { DON-15-GIcA, NIV, ZEA, } \\
\text { ZEA-14-GIcA, a-ZOL }\end{array}$ & $\begin{array}{l}\text { AFM }_{1}, \mathrm{OTA}, \mathrm{FB}_{1}, \mathrm{FB}_{2}, \mathrm{DON}, \mathrm{DON}-3- \\
\text { GICA, DON-15-GICA, NIV }\end{array}$ \\
\hline Ediage et al., 2012 & Belgium² & 40 & adults & $9(23 \%)$ & $\begin{array}{l}\text { DON, OTA, OTa, 4-OH- } \\
\text { OTA, ZEA, CIT, } \beta-Z O L\end{array}$ & DON, OTA, OTa, ZEA, $\beta$-ZOL \\
\hline $\begin{array}{l}\text { Shephard et al., } \\
2013\end{array}$ & South Africa ${ }^{2}$ & 53 & adult women & $53(100 \%)$ & $\begin{array}{l}\mathrm{OTA} \text { FB } \\
\text { 3-GI, DON, DON- } \\
\text { NIV, ZEA, ZEA-14-GIcA, } \\
\text { a-ZOL, } \beta-Z O L\end{array}$ & $\begin{array}{l}\text { OTA, FB, }{ }_{1} \text {, DON, DON-3-GIcA, DON- } \\
\text { 15-GICA, ZEA, ZEA-14-GIcA, a-ZOL, } \\
\beta \text {-ZOL }\end{array}$ \\
\hline $\begin{array}{l}\text { Rodriguez-Carrasco } \\
\text { et al., } 2014\end{array}$ & Valencia $^{2}$ & 54 & $\begin{array}{l}38 \text { adults, } \\
16 \text { children }\end{array}$ & $37(68.5 \%)$ & HT-2, NIV, DON & DON-HT2, DON-NIV \\
\hline Ezekiel et al., 2014 & Nigeria $^{2}$ & 120 & $\begin{array}{l}81 \text { adults, } \\
20 \text { adolescents, } \\
19 \text { children }\end{array}$ & $61(50.8 \%)$ & $\begin{array}{l}\mathrm{AFM}_{1}, \mathrm{DON}, \mathrm{DON}-15-\mathrm{GlcA} \\
\mathrm{FB}_{1}, \mathrm{FB}_{2}, \mathrm{OTA}, \mathrm{ZEA} \\
\text { ZEA-14-GIcA }\end{array}$ & $\begin{array}{l}\text { distribution of mycotoxins: } 75 \%(46 / 61) \\
\text { had a single mycotoxin and } 25 \% \\
\text { (15/61) had more than } 1 \text { mycotoxin [8 } \\
\text { had } 2 \text { different mycotoxins, } 5 \text { had } 3 \\
\text { different mycotoxins, } 2 \text { had } 4 \text { different } \\
\text { mycotoxins, } 7 \text { had more than one } \\
\text { mycotoxin/metabolite] }\end{array}$ \\
\hline Cao et al., 2013 & China $^{3}$ & 10 & $\begin{array}{l}6 \text { men, } \\
1 \text { pregnant woman, } \\
3 \text { lactating women }\end{array}$ & not stated & $\begin{array}{l}\text { AFB }_{1}, \mathrm{AFB}_{2}, \mathrm{HT}-2, \mathrm{DON} \\
\text { DOM-1, ZEA, a-ZOL, } \\
\text { ß-ZOL, FB }, \text { FB }_{2}, \mathrm{AFM}_{1} \\
\text { OTA, NEO, T-2 Triol }\end{array}$ & 3 samples had AFBs and FBs. \\
\hline Abia et al., 2013 & Cameroon $^{2}$ & & $\begin{array}{l}145 \text { HIV-positive } \\
\text { adults ( } 29 \text { male, } \\
116 \text { female), } \\
30 \text { HIV-negative } \\
\text { adults }\end{array}$ & $110(63 \%)$ & $\begin{array}{l}\text { DON, NIV, ZEA, OTA, FB, } \\
\text { FB, } \\
\text { 3-GICA, ZEA-14-GICA, } \\
\text { a-ZOL, AFM }\end{array}$ & DON, OTA, NIV, FB ${ }_{1}$, ZEA, AFM 1 , FB 2 \\
\hline Ediage et al., 2013 & Cameroon $^{2}$ & 220 & children & $160(73 \%)$ & $\begin{array}{l}\text { OTA, DON, AFM, } \text { FB }_{1} \\
\text { ZEA, } \alpha-Z O L, \beta-Z O L\end{array}$ & $\begin{array}{l}\text { co-occurrence of } 2,3 \text { and } 4 \text { mycotoxins } \\
\text { was } 35,5 \text { and } 5 \% \text {, respectively }\end{array}$ \\
\hline Solfrizzo et al., 2014 & Italy ${ }^{2}$ & 52 & $\begin{array}{l}26 \text { males, } \\
26 \text { females }\end{array}$ & $52(100 \%)$ & $\begin{array}{l}\text { DON, OTA, AFM }{ }_{1}, \text { FB }_{1} \\
\text { ZEA, } \alpha-Z O L, \beta-Z O L\end{array}$ & $\begin{array}{l}\text { distribution of mycotoxin mixtures in } \\
\text { samples: } 2 \text { (DON, ZEA, FB }{ }_{1} \text {, OTA, } \\
\left.\text { AFM }_{1}\right) ; 27 \text { (DON, ZEA, FB1, OTA); } \\
20 \text { (DON, ZEA, OTA); } 1 \text { (DON, ZEA, } \\
\text { OTA, AFM }_{1} \text { ); } 2 \text { (ZEA and OTA) }\end{array}$ \\
\hline Gerding et al., 2014 & Germany² & 101 & adult volunteers & $87 \%$ & $\begin{array}{l}\text { DON, ZEA, CIT, T-2, ENNB, } \\
\text { DON-3-GIcA, ZEA-14- } \\
\text { GIcA, DH-CIT }\end{array}$ & $\begin{array}{l}\text { DON-ENNB-ZEA, DON-CIT-T-2, DON- } \\
\text { CIT, DON-ZEA-DON-ENNB }\end{array}$ \\
\hline Gerding et al., 2015 & $\begin{array}{l}\text { Bangladesh }{ }^{2} \\
\text { Germany }^{2} \\
\text { Haiti }^{2}\end{array}$ & 287 & $\begin{array}{l}95 \text { adult } \\
\text { Bangladeshis, } \\
50 \text { adult Germans, } \\
142 \text { adult Haitians }\end{array}$ & $\begin{array}{l}\text { Bangladesh } \\
(87 \%), \\
\text { Germany } \\
(80 \%) \\
\text { Haiti }(68 \%)\end{array}$ & $\begin{array}{l}\text { DON, OTA, CIT, ENNB, } \\
\text { AFM }_{1} \text {, FB1, a-ZOL, DON- } \\
\text { 3-GICA, DH-CIT }\end{array}$ & $\begin{array}{l}\text { DON-CIT-OTA-FB, }{ }_{1} \text {, DON-CIT-OTA, } \\
\text { DON-OTA-ENNB, CIT-OTA-ENNB, } \\
\text { CIT-OTA-FB1, AFM }{ }_{1} \text {-CIT-OTA, } \\
\text { AFM }{ }_{1} \text {-CIT-DON, ENNB-OTA, DON- } \\
\text { OTA, CIT-OTA, CIT-FB }{ }_{1}, \text { CIT-ENNB, } \\
\text { AFM }{ }_{1} \text {-CIT }\end{array}$ \\
\hline \multicolumn{7}{|c|}{ 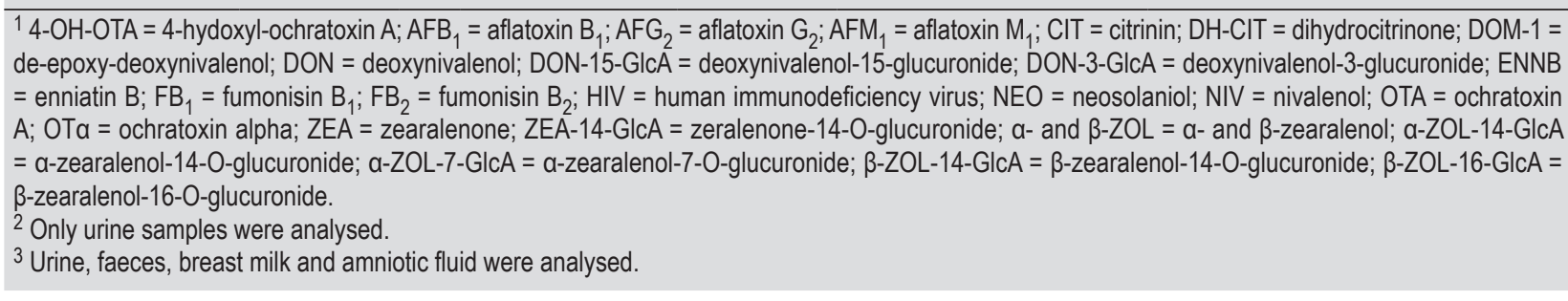 } \\
\hline
\end{tabular}


220 urine samples obtained from children in Cameroon, 160 (73\%) had biomarkers for OTA, DON, AFM, $\mathrm{FB}_{1}$, ZEA, $\alpha-Z O L$ and $\beta$-ZOL. Co-occurrence of 2,3 and 4 mycotoxins was 35, 5 and 5\%, respectively (Ediage et al., 2013). In a recent study in Nigeria, mycotoxins and their metabolites, including $\mathrm{AFM}_{1}$, DON, OTA, FB ${ }_{1}, \mathrm{FB}_{2}, \mathrm{FB}_{3}$, ZEA, zearalenone-14-O-glucuronide and deoxyvalenol-15O-glucuronide were detected in 51\% of urine samples from 120 volunteers involving children, adolescents and adults, and $25 \%$ of them indicated multi-mycotoxin exposure (Ezekiel et al., 2014). In another study in Italy (Solfrizzo et al., 2014), biomarkers of ZEA + ZOLs (100\%), OTA (100\%), DON (96\%), FB $156 \%$ ), and $\mathrm{AFM}_{1}$ were found in urine samples with $52 \%$ exposures involving mixtures of DON, ZEA, FB 1 and OTA. Furthermore, in a three-year survey of the global occurrence of mycotoxins using 7,049 feed and feedstuff samples, it was reported that $48 \%$ were contaminated by two or more mycotoxins (Rodrigues and Naehrer, 2012). Globally, the rate of co-occurrence of $\mathrm{AFB}_{1}$, DON, ZEA, OTA and fumonisins in feeds and feedstuff continues to be high (Schatzmayer and Streit, 2013) and therefore, requires toxicological consideration. Despite the fact that human beings can be exposed to a range of mixtures of mycotoxins, most toxicological studies have only taken into account of the effects of exposure to a single mycotoxin. However, combinations of mycotoxins can be agonistic, additive or antagonistic, and therefore, could pose a significant threat to human reproductive health (Alassane-Kpembi et al., 2013).

Epidemiological research evaluating the effects of mycotoxin mixtures on human reproduction is currently scarce, however, there are few in vitro studies evaluating their effects on the female and male reproductive system. Pizzo and colleagues examined the negative effects of single and combinations of DON, $\alpha-Z O L$ and $\beta-Z O L$ on cell proliferation, steroidogenesis and gene expression of bovine small-follicle granulosa cells after $48 \mathrm{~h}$ exposure $i n$ vitro (Pizzo et al., 2016). The presence of $\alpha$-ZOL (3.1 $\mu \mathrm{M})$ and $\beta-Z O L$ at $31 \mu \mathrm{M}$ significantly inhibited the growth of the bovine small-follicle granulosa cells whereas DON (0.1-3.3 $\mu \mathrm{M})$ had no significant effects on the graulosa cell proliferation. Worthy of note is that the exposure of the granulosa cells to binary combinations of $\alpha-\mathrm{ZOL}$ $(3.1 \mu \mathrm{M})$ and DON $(3.3 \mu \mathrm{M})$ significantly increased cell proliferation, indicating synergistic effects. In addition, combination of $\alpha-Z O L$ with DON or $\beta-Z O L$ inhibited oestradiol secretion higher than the effects obtained in single treatment of each of the toxins, but had no significant effect on progesterone production. In the same study (Pizzo et al., 2016), co-exposure of DON and $\beta$-ZOL to the granulosa cells decreased cell proliferation, and strongly inhibited oestradiol production. Similarly, DON with $\alpha$-ZOL or $\beta$-ZOL caused a significant up-regulation in the expression of $C Y P 11 A 1$ in IGF1 stimulated granuolsa cells. In a different study by Pizzo et al. (2015), the individual and combined effects of DON and $\alpha-Z O L$ on cell proliferation and steroidogenesis of follicle-stimulating hormone (FSH) plus IGF1 stimulated bovine large follicle granulosa cells was examined after $48 \mathrm{~h}$ of exposure. It was observed that DON $(3.3 \mu \mathrm{M})$ significantly reduced cell proliferation by $22 \%$ whereas $\alpha$-ZOL $(0.09$ and $0.31 \mu \mathrm{M})$ stimulated large granulosa cell growth. Interestingly, binary combination of DON $(0.01 \mu \mathrm{M})$ and $\alpha-\mathrm{ZOL}(0.09 \mu \mathrm{M})$ stimulated cell proliferation by $45 \%$ when compared to vehicle control, although this was not significantly different from the stimulatory effect of single treatment with $\alpha$-ZOL (0.09 $\mu \mathrm{M})$. It was also reported that that $\mathrm{DON}(0.33$ and $3.3 \mu \mathrm{M})$ significantly impaired both oestradiol and progesterone production compared to controls. Interestingly, coexposure of DON and $\alpha-Z O L$ to the granulosa cells in the presence of FSH inhibited progesterone secretion, but induced oestradiol production in the granulosa cells (Pizzo et al., 2015). Taken together, it can be deduced that coexposure of DON with $\alpha-Z O L$ or $\beta-Z O L$ at concentrations relevant to human exposure can impair bovine ovarian cell proliferation and steroidogenesis which may negatively affect normal follicle development and oocyte function. Therefore, human research should be taken to elucidate the molecular mechanisms through which co-exposure of DON with $\alpha-Z O L$ or $\beta$-ZOL affect ovarian function and morphology.

In a subsequent study, Albonico et al. (2016) evaluated the effects $F_{1}$ in single and combined with DON, $\alpha-Z O L$ or $\beta$-ZOL on bovine granulosa cells in the presence of IGF1 in vitro. $\mathrm{FB}_{1}(30 \mathrm{ng} / \mathrm{ml}-5 \mu \mathrm{g} / \mathrm{ml}), \alpha-\mathrm{ZOL}(5 \mu \mathrm{g} / \mathrm{ml})$ and $\beta-\mathrm{ZOL}$ $(30 \mathrm{ng} / \mathrm{ml})$ had no significant effect on the bovine granulosa cell growth. However, combination of $\mathrm{FB}_{1}(30 \mathrm{ng} / \mathrm{ml})$ with same concentration of $\beta$-ZOL significantly stimulated the cell growth. At higher concentrations, $\mathrm{FB}_{1}(5 \mu \mathrm{g} / \mathrm{ml})$ strongly reduced cell numbers, and co-exposure of $\mathrm{FB}_{1}(5$ $\mu \mathrm{g} / \mathrm{ml})$ with $\beta$-ZOL $(5 \mu \mathrm{g} / \mathrm{ml})$ also inhibited cell numbers. It was also reported that co-treatment of $\mathrm{FB}_{1}$ with $\alpha-\mathrm{ZOL}$ caused a significant decline in granulosa cell numbers, indicating either additive or synergistic effects as none of the mycotoxins had significant effect on cell numbers in a single exposure. On hormone production, $\mathrm{FB}_{1}$ (30 and $100 \mathrm{ng} / \mathrm{ml}$ ) had no effect on granulosa oestradiol secretion, but significantly stimulated its production at $5 \mu \mathrm{g} / \mathrm{ml}$. In contrast, $\alpha$-ZOL $(5 \mu \mathrm{g} / \mathrm{ml})$ and $\beta$-ZOL $(5 \mu \mathrm{g} / \mathrm{ml})$ strongly caused a decline in oestradiol production. In addition, combination of $\mathrm{FB}_{1}(5 \mu \mathrm{g} / \mathrm{ml})$ with $\alpha-\mathrm{ZOL}(5 \mu \mathrm{g} / \mathrm{ml})$ had no effect, but a co-exposure with $\beta$-ZOL $(5 \mu \mathrm{g} / \mathrm{ml})$ caused a reduction in oestradiol secretion. Surprisingly, co-treatment of $\mathrm{FB}_{1}$ alone or in combination with $\mathrm{DON}, \alpha-\mathrm{ZOL}$ or $\beta-\mathrm{ZOL}$ did not affect bovine granulosa cell progesterone release. In contradiction with the work of Albonico et al. (2016), Cortinovis and colleagues reported that co-treatment of $\mathrm{FB}_{1}$ with $\alpha$-ZOL amplified the level of progesterone produced by porcine small granulosa cells in single toxin exposure (Cortinovis et al., 2014), indicating additive effects. The 
difference in the response of porcine and bovine granuolsa cells to co-exposure of $\mathrm{FB}_{1}$ with $\alpha$-ZOL could be as a result of the species sensitivity of these mycotoxins. For instance, it is well known that $\mathrm{FB}_{1}$ is more toxic to horses and pigs than to cattle (Albonico et al., 2016). In an in vitro study, Tatay et al. (2014) studied the cytotoxic and interactive effects of ZEA, $\alpha-\mathrm{ZOL}$ and $\beta-\mathrm{ZOL}$ in ovarian (CHO-K1) cells. It was observed that binary or ternary combinations of these mycotoxins showed higher cytotoxicity than the individual toxins. In addition, co-exposure of ZEA with $\alpha$-ZOL or $\beta$-ZOL generally showed additive effects either at 24,48 or $72 \mathrm{~h}$ of exposure. Interestingly, ternary mixtures of ZEA, $\alpha-Z O L$ and $\beta-Z O L$ exhibited synergistic effects at lower concentrations (Tatay et al., 2014), further emphasising the need for the inclusion of mycotoxin mixtures in toxicological assessment. In summary, the co-occurrence of mycotoxins can cause perturbation in cell proliferation and dysregulation of endocrine function of ovarian cells, highlighting the significance of co-occurrence of mycotoxins to female reproductive health. Future research should also examine the role of co-occurrence of mycotoxins in placental morphology and function, embryogenesis and endometrial function.

The mechanisms through which mycotoxin mixtures can impact on testicular morphology and steroidogenesis also deserves attention. In a previous study, we have shown that DON, $\alpha-Z O L$ and OTA were strongly cytotoxic to MA-10 Leydig cells in vitro after $48 \mathrm{~h}$ of exposure (Eze et al., 2018). In the same study, OTA did not induce much cytotoxicity up to $16 \mu \mathrm{M}$ when cells were treated with only this compound, but co-exposure of OTA with DON increased the cytotoxicity at 8-32 $\mu \mathrm{M}$ compared to DON or OTA alone. In addition, OTA had a synergistic effect on the cytotoxicity induced by ZEA, $\alpha-Z O L$ and $\beta-Z O L$. We also reported that combinations of DON/OTA, DON/ ZEA, DON/ $\alpha-Z O L, D O N / \beta-Z O L, O T A / Z E A, O T A / \alpha-Z O L$, and OTA $/ \beta-Z O L$ were generally additive and synergistic at low concentrations (Eze et al., 2018), raising the possibility that co-exposure to these mycotoxins could contribute to adverse male reproductive health in exposed populations.

\section{Concluding remarks}

Mycotoxins are contaminants of many staple food crops for human consumption, particularly in sub-Saharan Africa and South Asia making these toxins a major public health, food safety and economic problem. There is scientific evidence on the adverse reproductive health effects of human exposure to mycotoxins in Africa, including low birth weight, stillbirth, intrauterine growth restriction, maternal anaemia, NTDs and male infertility. However, this review identified papers that were mainly cross-sectional studies and most of the studies did not adjust for other factors that could affect low birth weight, intrauterine growth restriction, male infertility, stillbirth, and anaemia, such as malaria, hormonal pathology, malnutrition, poor food quality, and other infectious disease conditions.

At present, the molecular pathways through which mycotoxins induce reproductive and developmental toxicity are still not well understood. Future research should employ validated biomarkers of mycotoxin exposure in human epidemiological studies, and reproductive cell lines or primary cells representing the reproductive system of both genders to investigate possible molecular pathways in which mycotoxins affect the reproductive systems, the sex gametes, placental and endometrial function, and embryogenesis. In addition, randomised control trials evaluating the effects of mycotoxins and poor reproductive health outcomes in humans using validated exposure biomarkers are urgently needed. Lastly, intervention strategies should be put in place in Africa to mitigate mycotoxin contamination of food crops, especially those consumed by vulnerable groups such as pregnant women, infants and young children.

\section{References}

Abia, W.A., Warth, B., Sulyok, M., Krska, R., Tchana, A., Njobeh, P.B., Turner, P.C., Kouanfack, C., Eyongetah, M., Dutton, M. and Moundipa, P.F., 2013. Bio-monitoring of mycotoxin exposure in Cameroon using a urinary multi-biomarker approach. Food and Chemical Toxicology 62: 927-934.

Abulu, E.O., Uriah, N., Aigbefo, H.S., Oboh, P.A. and Agbonlahor, D.E., 1997. Preliminary investigation on aflatoxin in cord blood of jaundiced neonates. West African Journal of Medicine 17: 184-187.

Adedara, I.A., Nanjappa, M.K., Faromi, E.O. and Akingbemi, B.T., 2014. Aflatoxin $B_{1}$ disrupts the androgen biopathway in rat Leydig cells. Food and Chemical Toxicology 65: 252-259.

Agarwal, A., Mulgund, A., Hamada, A. and Chyatte, M.R., 2015. A unique view on male infertility around the globe. Reproductive Biology and Endocrinology 13: 37.

Agnes, V.F. and Akbarsha, M.A., 2003. Spermatotoxic effect of aflatoxin $B_{1}$ in the albino mouse. Food and Chemical Toxicology 41: 119-130.

Ahmed, H., Hendrickse, R.G., Maxwell, S.M. and Yakubu, A.M., 1995. Neonatal jaundice with reference to aflatoxins: an aetiological study in Zaria, northern Nigeria. Annals of Tropical Paediatrics 15: 11-20.

Ahmed, K.A., El Mahady, M.M., Badawy, S.A., Ahmed, Y.F. and Aly, M.A., 2012. Pathological consequences of aflatoxins in male rabbit: cellular, genetic and oxidative damage. Global Veterinaria 9: 42-52.

Ahn, J., Kim, D., Kim, H. and Jahng, K.Y., 2010. Quantitative determination of mycotoxins in urine by LC-MS/MS. Food Additives and Contaminants Part A 27: 1674-1682.

Alassane-Kpembi, I., Kolf-Clauw, M., Gauthier, T., Abrami, R., Abiola, F.A., Oswald, I.P. and Puel, O., 2013. New insights into mycotoxin mixtures: the toxicity of low doses of type B trichothecenes on intestinal epithelial cells is synergistic. Toxicology and Applied Pharmacology 272: 191-198.

Albonico, M., Schütz, L.F., Caloni, F., Cortinovis, C. and Spicer, L.J., 2016. Toxicological effects of fumonisin $B_{1}$ alone and in combination with other fusariotoxins on bovine granulosa cells. Toxicon 118: 47-53. 
Alizadeh, A.M., Roshandel, G., Roudbarmohammadi, S., Roudbary, M., Sohanaki, H., Ghiasian, S.A., Taherkhani, A., Semnani, S. and Aghasi, M., 2012. Fumonisin $B_{1}$ contamination of cereals and risk of esophageal cancer in a high risk area in northeastern Iran. Asian Pacific Journal of Cancer Prevention 13: 2625-2628.

Alm, H., Bruessow, K.P., Torner, H., Vanselow, J., Tomek, W., Danicke, S. and Tiemann, U., 2006. Influence of Fusarium toxin contaminated feed on initial quality and meiotic competence of gilt oocytes. Reproductive Toxicology 22: 44-50.

Alm, H., Greising, T., Brüssow, K.P., Torner, H. and Tiemann, U., 2002. The influence of the mycotoxins deoxynivalenol and zearalenol on in vitro maturation of pig oocytes and in vitro culture of pig zygotes. Toxicology In Vitro 16: 643-648.

Andretta, I., Kipper, M., Lehnen, C.R. and Lovatto, P.A., 2012. Metaanalysis of the relationship of mycotoxins with biochemical and hematological parameters in broilers. Poultry Science 91: 376-382.

Asci, A., Durmaz, E., Erkekoglu, P., Pasli, D., Bircan, I. and KocerGumusel, B., 2014. Urinary zearalenone levels in girls with premature thelarche and idiopathic central precocious puberty. Minerva Pediatrica 66: 571-578.

Bacon, C.W., Porter, J.K. and Norred, W.P., 1995. Toxic interaction of fumonisin $B_{1}$ and fusaric acid measured by injection into fertile chicken egg. Mycopathologia 129: 29-35.

Baker, J., Liu, J.P., Robertson, E.J. and Efstratiadis, A., 1993. Role of insulin-like growth factors in embryonic and postnatal growth. Cell 75: 73-82.

Bandera, E.V., Chandran, U., Buckley, B., Lin, Y., Isukapalli, S., Marshall, I., King, M. and Zarbl, H., 2011. Urinary mycoestrogens, body size and breast development in New Jersey girls. Science of the Total Environment 409: 5221-5227.

Bolger, M., Coker, R.D., Dinovi, M., Gaylor, D., Gelderblom, M.O., Paster, N., Riley, R.T., Shephard, G. and Speijers, J.A., 2001. Fumonisins. In: Joint FAO/WHO Expert Committee on Food Additives (JECFA) (ed.) Safety evaluation of certain food additives and contaminants: prepared by the fifty-sixth meeting of the JECFA. Food Additives Series 47. WHO, Geneva, Switzerland, pp. 103-279.

Bulder, A.S., D. Arcella, M. Bolger, C. Carrington, K. and Resnik, S., 2012. Fumonisins (addendum). In: Joint FAO/WHO Expert Committee on Food Additives (JECFA) (ed.) Safety evaluation of certain food additives and contaminants: prepared by the seventyfourth meeting of the JECFA. Food Additives Series 65. WHO, Geneva, Switzerland, pp. 325-794.

Cao, X., Wu, S., Yue, Y., Wang, S., Wang, Y., Tao, L., Tian, H., Xie, J. and Ding, H., 2013. A high-throughput method for the simultaneous determination of multiple mycotoxins in human and laboratory animal biological fluids and tissues by PLE and HPLC-MS/MS. Journal of Chromatography B 942: 113-125.

Castelino, J.M., Dominguez-Salas, P., Routledge, M.N., Prentice, A.M., Moore, S.E., Hennig, B.J., Wild, C.P. and Gong, Y.Y., 2014. Seasonal and gestation stage associated differences in aflatoxin exposure in pregnant Gambian women. Tropical Medicine and International Health 19: 348-354.
Castelino, J.M., Routledge, M.N., Wilson, S., Dunne, D.W., Mwatha, J.K., Gachuhi, K., Wild, C.P. and Gong, Y.Y., 2015. Aflatoxin exposure is inversely associated with IGF1 and IGFBP3 levels in vitro and in Kenyan schoolchildren. Molecular Nutrition and Food Research 59: 574-581.

Chandra, A., Copen, C.E. and Stephen, E.H., 2013. Infertility and impaired fecundity in the United States, 1982-2010: data from the National Survey of Family Growth. National Health Statistics Reports no 67. National Center for Health Statistics, Hyattsville, MD, USA.

Chen, G., Gong, Y.Y., Kimanya, M.E., Shirima, C.P. and Routledge, M.N., 2018. Comparison of urinary aflatoxin M1 and aflatoxin albumin adducts as biomarkers for assessing aflatoxin exposure in Tanzanian children. Biomarkers 23: 131-136.

Collins, T.F., Sprando, R.L., Black, T.N., Olejnik, N., Eppley, R.M., Hines, F.A., Rorie, J. and Ruggles, D.I., 2006. Effects of deoxynivalenol (DON, vomitoxin) on in utero development in rats. Food and Chemical Toxicology 44: 747-757.

Cortinovis, C., Caloni, F., Schreiber, N.B. and Spicer, L.J., 2014. Effects of fumonisin $B_{1}$ alone and combined with deoxynivalenol or zearalenone on porcine granulosa cell proliferation and steroid production. Theriogenology 81: 1042-1049.

Dänicke, S., Brüssow, K.P., Goyarts, T., Valenta, H., Ueberschär, K.H. and Tiemann, U., 2007. On the transfer of the Fusarium toxins deoxynivalenol (DON) and zearalenone ( $\mathrm{ZON})$ from the sow to the full-term piglet during the last third of gestation. Food and Chemical Toxicology 45: 1565-1574.

De Vries, H.R., Maxwell, S.M. and Hendrickse, R.G., 1989. Foetal and neonatal exposure to aflatoxins. Acta Paediatrica 78: 373-378.

Debouck, C., Haubruge, E., Bollaerts, P., Van Bignoot, D., Brostaux, Y., Werry, A. and Rooze, M., 2001. Skeletal deformities induced by the intraperitoneal administration of deoxynivalenol (vomitoxin) in mice. International Orthopaedics 25: 194-198.

Deng, F., Tao, F.B., Liu, D.Y., Xu, Y.Y., Hao, J.H., Sun, Y. and Su, P.Y., 2012. Effects of growth environments and two environmental endocrine disruptors on children with idiopathic precocious puberty. European Journal of Endocrinology 166: 803-809.

Denning, D.W., Allen, R., Wilkinson, A.P. and Morgan, M.R., 1990. Transplacental transfer of aflatoxin in humans. Carcinogenesis 11: 1033-1035.

Ediage, E.N., Di Mavungu, J.D., Song, S., Sioen, I. and De Saeger, S., 2013. Multimycotoxin analysis in urines to assess infant exposure: a case study in Cameroon. Environment International 57: 50-59.

Ediage, E.N., Di Mavungu, J.D., Song, S., Wu, A., Van Peteghem, C. and De Saeger, S., 2012. A direct assessment of mycotoxin biomarkers in human urine samples by liquid chromatography tandem mass spectrometry. Analytica Chimica Acta 741: 58-69.

Eisa, A. and Metwally, A., 2011. Effect of glucomannan on haematological, coagulation and biochemical parameters in male rabbits fed aflatoxin-contaminated ration. World Mycotoxin Journal 4: 183-188.

Escrivá, L., Font, G. and Manyes, L., 2015. In vivo toxicity studies of Fusarium mycotoxins in the last decade: a review. Food and Chemical Toxicology 78: 185-206.

Etuk, S.J., 2009. Reproductive health: global infertility trend. Nigerian Journal of Physiological Sciences 24: 85-90. 
European Food Safety Authority (EFSA), 2017a. Scientific Opinion on the risks to human and animal health related to the presence of deoxynivalenol and its acetylated and modified forms in food and feed. EFSA Journal 15: 4718.

European Food Safety Authority (EFSA), 2017b. Scientific Opinion on the risks for animal health related to the presence of zearalenone and its modified forms in feed. EFSA Journal 15: 4851.

Ewuola, E.O. and Egbunike, G.N., 2010. Effects of dietary fumonisin $B_{1}$ on the onset of puberty, semen quality, fertility rates and testicular morphology in male rabbits. Reproduction 13: 439-445.

Eze, U.A. and Okonofua, F.E., 2015. High prevalence of male infertility in Africa: are mycotoxins to blame? Editorial. African Journal of Reproductive Health 19: 9-17.

Eze, U.A., Huntriss, J., Routledge, M.N. and Gong, Y.Y., 2018. Toxicological effects of regulated mycotoxins and persistent organochloride pesticides: in vitro cytotoxic assessment of single and defined mixtures on MA-10 murine Leydig cell line. Toxicology In Vitro 48: 93-103.

Ezekiel, C.N., Warth, B., Ogara, I.M., Abia, W.A., Ezekiel, V.C., Atehnkeng, J., Sulyok, M., Turner, P.C., Tayo, G.O., Krska, R. and Bandyopadhyay, R., 2014. Mycotoxin exposure in rural residents in northern Nigeria: a pilot study using multi-urinary biomarkers. Environment International 66: 138-145.

Floss, J.L., Casteel, S.W., Johnson, G.C., Rottinghaus, G.E. and Krause, G.F., 1994. Development toxicity of fumonisin in Syrian hamsters. Mycopathologia 128: 33-38.

Flynn, T.J., Pritchard, D., Bradlaw, J., Eppley, R. and Page S., 1996. In vitro embryotoxicity of fumonisin $\mathrm{B}_{1}$ evaluated with cultured postimplantation staged rat embryos. Toxicology In Vitro 9: 271-279.

Gbore, F.A., 2009a. Growth performance and puberty attainment in growing pigs fed dietary fumonisin $\mathrm{B}_{1}$. Journal of Animal Physiology and Animal Nutrition 93: 761-767.

Gbore, F.A., 2009b. Reproductive organ weights and semen quality of pubertal boars fed dietary fumonisin $B_{1}$. Animal 3: 1133-1137.

Gbore, F.A. and Egbunike, G.N., 2008. Testicular and epididymal sperm reserves and sperm production of pubertal boars fed dietary fumonisin $B_{1}$. Animal Reproduction Science 105: 392-397.

Gbore, F.A., Owolawi, T.J., Erhunwunsee, M., Akele, O. and GabrielAjobiewe, R.A.O., 2012. Evaluation of the reproductive toxicity of dietary fumonisin $B_{1}$ in rats. Jordan Journal of Biological Sciences 5: 183-190.

Gelderblom, W.C., Kriek, N.P., Marasas, W.F. and Thiel, P.G., 1991. Toxicity and carcinogenicity of the Fusarium moniliforme metabolite, fumonisin $B_{1}$, in rats. Carcinogenesis 12: 1247-1251.

Gelineau-Van Waes, J., Rainey, M.A., Maddox, J.R., Voss, K.A., Sachs, A.J., Gardner, N.M., Wilberding, J.D. and Riley, R.T., 2012. Increased sphingoid base-1-phosphates and failure of neural tube closure after exposure to fumonisin or FTY720. Birth Defects Research Part A: Clinical and Molecular Teratology 94: 790-803.

Gelineau-Van Waes, J., Starr, L., Maddox, J.R., Aleman, F., Voss, K.A., Wilberding, J. and Riley, R.T., 2005. Maternal fumonisin exposure and risk for neural tube defects: disruption of sphingolipid metabolism and folate transport in an in vivo mouse model. Birth Defects Research part A: Clinical and Molecular Teratology 73: 487-497.
Gelineau-Van Waes, J., Voss, K.A., Stevens, V.L., Speer, M.C. and Riley, R.T., 2009. Maternal fumonisin exposure as a risk factor for neural tube defects. Advances in Food and Nutrition Research 56: 145-181. Gerding, J., Ali, N., Schwartzbord, J., Cramer, B., Brown, D.L., Degen, G.H. and Humpf, H.U., 2015. A comparative study of the human urinary mycotoxin excretion patterns in Bangladesh, Germany, and Haiti using a rapid and sensitive LC-MS/MS approach. Mycotoxin Research 31: 127-136.

Gerding, J., Cramer, B. and Humpf, H.U., 2014. Determination of mycotoxin exposure in Germany using an LC-MS/MS multibiomarker approach. Molecular Nutrition and Food Research 58: 2358-2368.

Gong, Y.Y., Shirima, C.P., Srey, C., Kimanya, M.E. and Routledge, M.N., 2015. Deoxynivalenol and fumonisin exposure in children and adults in a family study in Tanzania. World Mycotoxin Journal 8: 553-560.

Gong, Y.Y., Torres-Sanchez, L., Lopez-Carrillo, L., Peng, J.H., Sutcliffe, A.E., White, K.L., Humpf, H.U., Turner, P.C. and Wild, C.P., 2008. Association between tortilla consumption and human urinary fumonisin $B_{1}$ levels in a Mexican population. Cancer Epidemiology and Prevention Biomarkers 17: 688-694.

Goyarts, T., Dänicke, S., Brüssow, K.P., Valenta, H., Ueberschär, K.H. and Tiemann, U., 2007. On the transfer of the Fusarium toxins deoxynivalenol (DON) and zearalenone ( $\mathrm{ZON}$ ) from sows to their fetuses during days 35-70 of gestation. Toxicology Letters 171: 38-49. Greene, N.D. and Copp, A.J., 2005. Mouse models of neural tube defects: investigating preventive mechanisms. American Journal of Medical Genetics Part C: Seminars in Medical Genetics 135: 31-41.

Han, J., Wang, Q.C., Zhu, C.C., Liu, J., Zhang, Y., Cui, X.S., Kim, N.H. and Sun, S.C., 2016. Deoxynivalenol exposure induces autophagy/ apoptosis and epigenetic modification changes during porcine oocyte maturation. Toxicology and Applied Pharmacology 300: 70-76.

Harrison, L.R., Colvin, B.M., Greene, J.T., Newman, L.E. and Cole Jr, J.R., 1990. Pulmonary edema and hydrothorax in swine produced by fumonisin $\mathrm{B}_{1}$, a toxic metabolite of Fusarium moniliforme. Journal of Veterinary Diagnostic Investigation 2: 217-221.

Haschek, W.M., Gumprecht, L.A., Smith, G., Tumbleson, M.E. and Constable, P.D., 2001. Fumonisin toxicosis in swine: an overview of porcine pulmonary edema and current perspectives. Environmental Health Perspectives 109: 251-257.

Hendricks, K., 1999. Fumonisins and neural tube defects in South Texas. Epidemiology 10: 198-200.

Hernandez-Vargas, H., Castelino, J., Silver, M.J., Dominguez-Salas, P., Cros, M.P., Durand, G., Calvez-Kelm, F.L., Prentice, A.M., Wild, C.P., Moore, S.E. and Hennig, B.J., 2015. Exposure to aflatoxin $B_{1}$ in utero is associated with DNA methylation in white blood cells of infants in The Gambia. International Journal of Epidemiology 44: 1238-1248.

Hou, Y.J., Xiong, B., Zheng, W.J., Duan, X., Cui, X.S., Kim, N.H., Wang, Q., Xu, Y.X. and Sun, S.C., 2014. Oocyte quality in mice is affected by a mycotoxin-contaminated diet. Environmental and Molecular Mutagenesis 55: 354-362.

Howard, P.C., Eppley, R.M., Stack, M.E., Warbritton, A., Voss, K.A., Lorentzen, R.J., Kovach, R.M. and Bucci, T.J., 2001b. Fumonisin $\mathrm{B}_{1}$ carcinogenicity in a two-year feeding study using F344 rats and B6C3F1 mice. Environmental Health Perspectives 109: 277-282. 
Howard, P.C., Warbritton, A., Voss, K.A., Lorentzen, R.J., Thurman, J.D., Kovach, R.M. and Bucci, T.J., 2001a. Compensatory regeneration as a mechanism for renal tubule carcinogenesis of fumonisin $B_{1}$ in the F344/N/Nctr BR rat. Environmental Health Perspectives 109: 309-314.

Ibeh, I.N., Saxena, D.K. and Uriah, N., 2000. Toxicity of aflatoxin: effects on spermatozoa, oocytes, and in vitro fertilization. Journal of Environmental Pathology, Toxicology and Oncology 19: 357-361.

Ibeh, I.N., Uriah, N. and Ogonar, J.I., 1994. Dietary exposure to aflatoxin in human male fertility in Benin City, Nigeria. International Journal of Fertility 39: 208-214.

International Agency for Research on Cancer (IARC), 2002. Monograph on the evaluation of carcinogenic risks to humans. Vol. 82. Some traditional herbal medicines, some mycotoxins, naphthalene and styrene. IARC, Lyon, France.

International Food Policy Research Institute (IFPRI), 2016. Global Nutrition Report 2016: From promise to impact - ending malnutrition by 2030. IFPRI, Washington DC, USA.

Ito, Y., Ohtsubo, K., Ishii, K. and Ueno, Y., 1986. Effects of nivalenol on pregnancy and fetal development of mice. Mycotoxin Research 2: 71-77.

Ito, Y., Ueno, Y., Tanaka, T., Nakamura, K. and Ohtsubo, K., 1988. Embryotoxicity of oral nivalenol in mice. JSM Mycotoxins 1988: 33-36.

Javed, T., Richard, J.L., Bennett, G.A., Dombrink-Kurtzman, M.A., Bunte, R.M., Koelkebeck, K.W., Côté, L.M., Leeper, R.W. and Buck, W.B., 1993. Embryopathic and embryocidal effects of purified fumonisin $\mathrm{B}_{1}$ or Fusarium proliferatum culture material extract on chicken embryos. Mycopathologia 123: 185-193.

Jolly, P., Jiang, Y., Ellis, W., Awuah, R., Nnedu, O., Phillips, T., Wang, J.S., Afriyie-Gyawu, E., Tang, L., Person, S. and Williams, J., 2006. Determinants of aflatoxin levels in Ghanaians: sociodemographic factors, knowledge of aflatoxin and food handling and consumption practices. International Journal of Hygiene and Environmental Health 209: 345-358.

Kensler, T. W., Roebuck, B. D., Wogan, G. N. and Groopman, J. D., 2011. Aflatoxin: a 50 year odyssey of mechanistic and translational research. Toxicological Science 99: S28-48.

Khan, K.S., Wojdyla, D., Say, L., Gülmezoglu, A.M. and Van Look, P.F., 2006. WHO analysis of causes of maternal death: a systematic review. The Lancet 367: 1066-1074.

Khera, K.S., Arnold, D.L., Whalen, C., Angers, G. and Scott, P.M., 1984. Vomitoxin (4-deoxynivalenol): effects on reproduction of mice and rats. Toxicology and Applied Pharmacology 74: 345-356.

Khera, K.S., Whalen, C. and Angers, G., 1986. A teratology study on vomitoxin (4-deoxynivalenol) in rabbits. Food and Chemical Toxicology 24: 421-424.

Khera, K.S., Whalen, C., Angers, G., Vesonder, R.F. and KuiperGoodman, T., 1982. Embryotoxicity of 4-deoxynivalenol (vomitoxin) in mice. Bulletin of Environmental Contamination and Toxicology 29: 487-491.

Kirilov, M., Clarkson, J., Liu, X., Roa, J., Campos, P., Porteous, R., Schütz, G. and Herbison, A.E., 2013. Dependence of fertility on kisspeptin-Gpr54 signaling at the GnRH neuron. Nature Communications 4: 2492.
Komsky-Elbaz, A., Saktsier, M. and Roth, Z., 2018. Aflatoxin B impairs sperm quality and fertilization competence. Toxicology 393: 42-50.

Kriszt, R., Winkler, Z., Polyák, Á., Kuti, D., Molnár, C., Hrabovszky, E., Kalló, I., Szőke, Z., Ferenczi, S. and Kovács, K.J., 2015. Xenoestrogens ethinyl estradiol and zearalenone cause precocious puberty in female rats via central kisspeptin signaling. Endocrinology 156: 3996-4007.

Kumar, R. and Balachandran, C., 2005. Haematological and biochemical alterations in broiler chicken fed aflatoxin and cyclopiazonic acid. Indian Veterinary Journal 82: 1255-1257.

Lamplugh, S., Hendrickse, R., Apeagyei, F. and Mwanmut, D., 1988. Aflatoxins in breast milk, neonatal cord blood, and serum of pregnant women. British Medical Journal 296: 968.

Lanza, G., Washburn, K.W. and Wyatt, R.D., 1978. Relationship of iron-absorption to development of aflatoxin related anemia. Poultry Science 57: 1104-1104.

Leger, J., Oury, J.F., Noel, M., Baron, S., Benali, K., Blot, P. and Czernichow, P., 1996. Growth factors and intrauterine growth retardation. I. Serum growth hormone, insulin-like growth factor (IGF)-I, IGF-II, and IGF binding protein 3 levels in normally grown and gestation. Pediatric Research 40: 94-100.

Leroy, J.L., Wang, J.S. and Jones, K., 2015. Serum aflatoxin $B_{1}$-lysine adduct level in adult women from Eastern Province in Kenya depends on household socio-economic status: a cross sectional study. Social Science and Medicine 146: 104-110.

Marasas, W.F.O., Jaskiewicz, K., Venter, F.S. and van Schalkwyk, D. J., 1988. Fusarium moniliforme contamination of maize in oesophageal cancer areas in Transkei. South African Medical Journal 74: 110-14.

Marasas, W.F.O, Riley, R.T., Hendricks, K.A., Stevens, V.L., Sadler, T.W. and Gelineau-Van Waes, J., 2004. Fumonisins disrupt sphingolipid metabolism, folate transport, and neural tube development in embryo culture and in vivo: a potential risk factor for human neural tube defects among populations consuming fumonisincontaminated maize. Journal of Nutrition 134: 711-16.

Mascarenhas, M.N., Flaxman, S.R., Boerma, T., Vanderpoel, S. and Stevens, G.A., 2012. National, regional, and global trends in infertility prevalence since 1990: a systematic analysis of 277 health surveys. PLoS Medicine. 9: e1001356.

Massart, F. and Saggese, G., 2010. Oestrogenic mycotoxin exposures and precocious puberty development. International Journal of Andrology 33: 369-376.

Massart, F., Meucci, V., Saggese, G. and Soldani, G., 2008. High growth rate of girls with precocious puberty exposed to oestrogenic mycotoxins. Journal of Paediatrics 152: 690-695.

Maxwell, S.M., Familusi, J.B., Sodeinde, O., Chan, M.C.K. and Hendrickse, R.G., 1994. Detection of naphthols and aflatoxins in Nigerian cord blood. Annals of Tropical Paediatrics 14: 3-5.

McClure, E.M., Saleem, S., Pasha, O. and Goldenberg, R.L., 2009. Stillbirth in developing countries: a review of causes, risk factors and prevention strategies. The Journal of Maternal-fetal and Neonatal Medicine 22: 183-190.

Melnick, M. and Marazita, M.L., 1998. Neural tube defects, methylenetetrahydrofolate reductase mutation, and north/south dietary. Journal of Craniofacial Genetics and Developmental Biology 18: 233-235. 
Merrill Jr., A.H., Sullards, M.C., Wang, E., Voss, K.A. and Riley, R.T., 2001. Sphingolipid metabolism: roles in signal transduction and disruption by fumonisins. Environmental Health Perspectives 109: 283-289.

Misihairabgwi, J.M., Ezekiel, C.N., Sulyok, M., Shephard, G.S. and Krska, R., in press. Mycotoxin contamination of foods in Southern Africa: a 10-year review (2007-2016). Critical Reviews in Food Science and Nutrition, DOI: https://doi.org/10.1080/10408398.2 017.1357003

Missmer, S.A., Suarez, L., Felkner, M., Wang, E., Merrill Jr, A.H., Rothman, K.J. and Hendricks, K.A., 2006. Exposure to fumonisins and the occurrence of neural tube defects along the Texas-Mexico border. Environmental Health Perspectives 114: 237-241.

Mohammed, M.N., Ameen, M.M., Mohammed, O.A., Al-Maghraby, O.M., Aziz, O.A., Ahmed, S.R. and Alsammani, M.A., 2014. The effect of aflatoxins on male reproduction. Medical Archives 68: 272-275.

Nielsen, J.K., Vikström, A.C., Turner, P. and Knudsen, L.E., 2011 Deoxynivalenol transport across the human placental barrier. Food and Chemical Toxicology 49: 2046-2052.

Oakley, L., Doyl,e P. and Maconochie, N., 2008. Lifetime prevalence of infertility and infertility treatment in the UK: results from a population-based survey of reproduction. Human Reproduction 23: 447-450.

Obremski, K., Gajęck,i M., Zwierzchowski, W., Zielonka, L., OtrockaDomagala, I., Rotkiewicz, T., Mikolajczyk, A., Gajęcka, M. and Polak, M., 2003. Influence of zearalenone on reproductive system cell proliferation in gilts. Polish Journal of Veterinary Science 6: 239-245.

Okonofua, F.E., Menakaya, U., Onemu, S.O., Tita, B. and Bergstrom, S., 2005. A case-referent study of risk factors for male infertility in southern Nigeria. Asian Journal of Andrology 7: 351-361.

Ortatatli, M., Clifci, M.K., Tuzcu, M. and Kaya, A., 2002. The effects of aflatoxin on the reproductive system of roosters. Research in Veterinary Medicine 72: 29-36.

Ota, E., Ganchimeg, T., Morisaki, N., Vogel, J.P., Pileggi, C., OrtizPanozo, E., Souza, J.P., Mori, R. and WHO Multi-Country Survey on Maternal and Newborn Health Research Network., 2014. Risk factors and adverse perinatal outcomes among term and preterm infants born small-for-gestational-age: secondary analyses of the WHO Multi-Country Survey on Maternal and Newborn Health. PLoS One9: e105155.

Partanen, H.A., El-Nezami, H.S., Leppänen, J.M., Myllynen, P.K., Woodhouse, H.J. and Vähäkangas, K.H., 2009. Aflatoxin $B_{1}$ transfer and metabolism in human placenta. Toxicological Sciences 113: 216-225.

Payros, D., Alassane-Kpembi, I., Pierron, A., Loiseau, N., Pinton, P. and Oswald, I.P., 2016. Toxicology of deoxynivalenol and its acetylated and modified forms. Archives of Toxicology 90: 2931-2957.

Pestka, J.J., 2010a. Toxicological mechanisms and potential health effects of deoxynivalenol and nivalenol. World Mycotoxin Journal 3: 323-347.

Pestka, J.J., 2010b. Deoxynivalenol: mechanisms of action, human exposure, and toxicological relevance. Archives of Toxicology 84: 663-679.
Picha, J., Cerovsky, J. and Pichova, D., 1986. Fluctuation in the concentration of sex steroids and aflatoxin $\mathrm{B}_{1}$ in the seminal plasma of boars and its relation to sperm production. Veterinarni Medicina 36: 347-357.

Piekkola, S., Turner, P.C., Abdel-Hamid, M., Ezzat, S., El-Daly, M., El-Kafrawy, S., Savchenko, E., Poussa, T., Woo, J.C.S., Mykkänen, H. and El-Nezami, H., 2012. Characterisation of aflatoxin and deoxynivalenol exposure among pregnant Egyptian women. Food Additives and Contaminants: Part A 29: 962-971.

Pizzo, F., Caloni, F., Schreiber, N.B., Cortinovis, C. and Spicer, L.J., 2016. In vitro effects of deoxynivalenol and zearalenone major metabolites alone and combined, on cell proliferation, steroid production and gene expression in bovine small-follicle granulosa cells. Toxicon 109: 70-83.

Pizzo, F., Caloni, F., Schutz, L.F., Totty, M.L. and Spicer, L.J., 2015. Individual and combined effects of deoxynivalenol and $\alpha$-zearalenol on cell proliferation and steroidogenesis of granulosa cells in cattle. Environmental Toxicology and Pharmacology 40: 722-728.

Rheeder, J.P., Marasas, W.F.O., Thiel, P.G., Sydenham, E.W., Shephard, G.S. and Van Schalkwy, D.J., 1992. Fusarium moniliforme and fumonisins in corn in relation to human esophageal cancer in Transkei. Phytopathology 82: 353-357.

Rheeder, J.P., Van der Westhuizen, L., Imrie, G. and Shephard, G. S., 2016. Fusarium species and fumonisins in subsistence maize in the former Transkei region, South Africa: a multi-year study in rural villages. Food Additives and Contaminants: Part B 9: 176-184.

Riley, R.T. and Voss, K.A., 2006. Differential sensitivity of rat kidney and liver to fumonisin toxicity: organ-specific differences in toxin accumulation and sphingolipid base metabolism. Toxicological Sciences 92: 335-345.

Rodrigues, I. and Naehrer, K., 2012. A three-year survey on the worldwide occurrence of mycotoxins in feedstuffs and feed. Toxins 4: 663-675.

Rodríguez-Carrasco, Y., Moltó, J.C., Mañes, J. and Berrada, H., 2014. Exposure assessment approach through mycotoxin/creatinine ratio evaluation in urine by GC-MS/MS. Food and Chemical Toxicology 72: 69-75.

Rubert, J., Soriano, J.M., Mañes, J. and Soler, C., 2011. Rapid mycotoxin analysis in human urine: a pilot study. Food and Chemical Toxicology 49: 2299-2304.

Sadler, T.W., Merrill, A.H., Stevens, V.L., Sullards, M.C., Wang, E. and Wang, P., 2002. Prevention of fumonisin $B_{1}$-induced neural tube defects by folic acid. Teratology 66: 169-176.

Šarkanj, B., Warth, B., Uhlig, S., Abia, W.A., Sulyok, M., Klapec, T., Krska, R. and Banjari, I., 2013. Urinary analysis reveals high deoxynivalenol exposure in pregnant women from Croatia. Food and Chemical Toxicology 62: 231-237.

Savard, C., Nogues, P., Boyer, A. and Chorfi, Y., 2016. Prevention of deoxynivalenol-and zearalenone-associated oxidative stress does not restore MA-10 Leydig cell functions. Toxicology 341: 17-27.

Schatzmayr. G. and Streit, E., 2013. Global occurrence of mycotoxins in the food and feed chain: facts and figures. World Mycotoxin Journal 6: 213-222.

Schoental, R., 1983. Precocious sexual development in Puerto Rico and oestrogenic mycotoxins (zearalenone). The Lancet 321: 537. 
Semple, R.K., Achermann, J.C., Ellery, J., Farooqi, I.S., Karet, F.E., Stanhope, R.G., O'rahilly, S. and Aparicio, S.A., 2005. Two novel missense mutations in g protein-coupled receptor 54 in a patient with hypogonadotropic hypogonadism. Journal of Clinical Endocrinology and Metabolism 90: 1849-1855.

Shephard, G.S., Burger, H.M., Gambacorta, L., Gong, Y.Y., Krska, R., Rheeder, J.P., Solfrizzo, M., Srey, C., Sulyok, M., Visconti, A. and Warth, B., 2013. Multiple mycotoxin exposure determined by urinary biomarkers in rural subsistence farmers in the former Transkei, South Africa. Food and Chemical Toxicology 62: 217-225.

Shephard, G.S., Marasas, W.F.O., Yazdanpanah, H., Rahimian, H., Safavi, N., Zarghi, A., Shafaati, A. and Rasekh, H.R., 2002. Fumonisin $\mathrm{B}_{1}$ in maize harvested in Iran during 1999. Food Additives and Contaminants 19: 676-679.

Shephard, G.S., Van der Westhuizen, L. and Sewram, V., 2007. Biomarkers of exposure to fumonisin mycotoxins: a review. Food Additives and Contaminants 24: 1196-1201.

Shirima C.P., Kimanya M.E., Kinabo J.L., Routledge M.N., Srey C., Wild C.P. and Gong Y.Y., 2013. Dietary exposure to aflatoxin and fumonisin among Tanzanian children as determined using biomarkers of exposure. Molecular Nutrition and Food Research 57: 1874-1881.

Shuaib, F.M., Ehiri, J., Abdullahi, A., Williams, J.H. and Jolly, P.E., 2010a. Reproductive health effects of aflatoxins: a review of the literature. Reproductive Toxicology 29: 262-270.

Shuaib, F.M., Jolly, P.E., Ehiri, J.E., Yatich, N., Jiang, Y., Funkhouser, E., Person, S.D., Wilson, C., Ellis, W.O., Wang, J.S. and Williams, J.H., 2010c. Association between birth outcomes and aflatoxin $B_{1}$ biomarker blood levels in pregnant women in Kumasi, Ghana. Tropical Medicine and International Health 15: 160-167.

Shuaib, F.M., Jolly, P.E., Ehiri, J.E., Jiang, Y., Ellis, W.O., Stiles, J.K., Yatich, N.J., Funkhouser, E., Person, S.D., Wilson, C. and Williams, J.H., 2010b. Association between anemia and aflatoxin $B_{1}$ biomarker levels among pregnant women in Kumasi, Ghana. The American Journal of Tropical Medicine and Hygiene 83: 1077-1083.

Shuaib, F.M.B., Jolly, P.E., Ehiri, J.E., Ellis, W.O., Yatich, N.J., Funkhouser, E., Person, S.D., Williams, J.H., Qian, G. and Wang, J.S., 2012. Sociodemographic determinants of aflatoxin $B_{1}$-lysine adduct levels among pregnant women in Kumasi, Ghana. Ghana Medical Journal 46: 179-188.

Skorska-Wyszyńska, E., Gajęcka, M., Polak, M., Jakimiuk, E., Jana, B., Rybarczyk, L. and Gajęcki, M., 2005. Level of zearalenone in blood serum and lesions in ovarian follicles of sexually immature gilts in the course of zearalenone micotoxicosis. Polish Journal of Veterinary Sciences 8: 209-218.

Smith, G.W., Constable, P.D., Foreman, J.H., Eppley, R.M., Waggoner, A.L., Tumbleson, M.E. and Haschek, W.M., 2002. Cardiovascular changes associated with intravenous administration of fumonisin $B_{1}$ in horses. American Journal of Veterinary Research 63: 538-545.

Smith, L.E., Mbuya, M.N., Prendergast, A.J., Turner, P.C., Ruboko, S., Humphrey, J.H., Nelson, R.J., Chigumira, A., Kembo, G. and Stoltzfus, R.J., 2017b. Determinants of recent aflatoxin exposure among pregnant women in rural Zimbabwe. Molecular Nutrition and Food Research 61: 1601049.
Smith, L.E., Prendergast, A.J., Turner, P.C., Humphrey, J.H. and Stoltzfus, R.J., 2017a. Aflatoxin exposure during pregnancy, maternal anemia, and adverse birth outcomes. American Journal of Tropical Medicine and Hygiene 96: 770-776.

Solfrizzo, M., Gambacorta, L. and Visconti, A., 2014. Assessment of multi-mycotoxin exposure in southern Italy by urinary multibiomarker determination. Toxins 6: 523-538.

Solfrizzo, M., Gambacorta, L., Lattanzio, V.M., Powers, S. and Visconti, A., 2011. Simultaneous LC-MS/MS determination of aflatoxin $\mathrm{M}_{1}$, ochratoxin A, deoxynivalenol, de-epoxydeoxynivalenol, $\alpha$ and $\beta$-zearalenols and fumonisin $B_{1}$ in urine as a multi-biomarker method to assess exposure to mycotoxins. Analytical and Bioanalytical Chemistry 401: 2831-2841.

Sprando, R.L., Collins, T.F., Black, T.N., Olejnik, N., Rorie, J.I., Eppley, R.M. and Ruggles, D.I., 2005. Characterization of the effect of deoxynivalenol on selected male reproductive endpoints. Food and Chemical Toxicology 43: 623-635.

Sprando, R.L., Pestka, J., Collins, T.F.X., Rorie, J., O'donnell, M., Hinton, D. and Chirtel, S., 1999. The effect of vomitoxin (deoxnivalenol) on testicular morphology, testicular spermatid counts and epididymal sperm counts in IL-6KO [B6129-IL6[tmlKopf](IL6 gene deficient)] and WT [B6129F2 (wild type to B6129-IL6 with an intact IL-6 gene)] mice. Food and Chemical Toxicology 37: 1073-1079.

Sugita-Konishi, Y., Kubosaki, A., Takahashi, M., Park, B.J., Tanaka, T., Takatori, K., Hirose, M. and Shibutani, M., 2008. Nivalenol and the targeting of the female reproductive system as well as haematopoietic and immune systems in rats after 90-day exposure through the diet. Food Additives and Contaminants Part A 25: 1118-1127.

Sun, G., Wang, S. and Hu, X., 2007. Fumonisin $B_{1}$ contamination of home-grown corn in high-risk areas for esophageal and liver cancer in China. Food Additives and Contaminants 24: 181-185.

Supriya, C., Girish, B.P. and Reddy, P.S., 2014. Aflatoxin B B $_{1}$-induced reproductive toxicity in male rats: possible mechanism of action. International Journal of Toxicology 33: 155-161.

Szuets, P., Mesterhazy, A., Falkay, G.Y. and Bartok, T., 1997. Early thelarche symptoms in children and their relations to zearalenone contamination in foodstuffs. Cereal Research Communications 25: 429-436.

Takahashi, M., Shibutani, M., Sugita-Konishi, Y., Aihara, M., Inoue, K., Woo, G.H., Fujimoto, H. and Hirose, M., 2008. A 90-day subchronic toxicity study of nivalenol, a trichothecene mycotoxin, in F344 rats. Food and Chemical Toxicology 46: 125-135.

Tatay, E., Meca, G., Font, G. and Ruiz, M.J., 2014. Interactive effects of zearalenone and its metabolites on cytotoxicity and metabolization in ovarian CHO-K1 cells. Toxicology In Vitro 28: 95-103.

Tomaszewski, J., Miturski, R., Semczuk, A., Kotarski, J. and Jakowicki, J., 1998. Tissue zearalenone concentration in normal, hyperplastic and neoplastic human endometrium. Ginekologia Polska 69: 363366.

Turner, P.C., Collinson, A.C., Cheung, Y.B., Gong, Y., Hall, A.J., Prentice, A.M. and Wild, C.P., 2007. Aflatoxin exposure in utero causes growth faltering in Gambian infants. International Journal of Epidemiology 36: 1119-1125. 
Uriah, N., Ibeh, N.I. and Oluwafemi, F., 2001. A study on the impact of aflatoxin on human reproduction. African Journal of Reproductive Health 5: 106-110.

Van der Westhuizen, L., Shephard, G.S. and Van Schalkwyk, D.J., 2001. The effect of repeated gavage doses of fumonisin $B_{1}$ on the sphinganine and sphingosine levels in vervet monkeys. Toxicon 39: 969-972.

Van der Westhuizen, L., Shepherd, G.S., Burger, H.M., Rheeder, J.P., Gelderblom, W.C.A., Wild, C.P. and Gong, Y.Y., 2011. Fumonisin $\mathrm{B}_{1}$ as urinary biomarker of exposure in a maize intervention study among South African subsistence farmers. Cancer Epidemiology, Biomarkers and Prevention 20: 483-489.

Van der Westhuizen, L., Shephard, G.S., Rheeder, J.P. and Burger, H.M., 2010. Individual fumonisin exposure and sphingoid base levels in rural populations consuming maize in South Africa. Food and Chemical Toxicology 48: 1698-1703.

Van der Westhuizen, L., Shephard, G.S., Rheeder, J.P., Somdyala, N.I.M. and Marasas, W.F.O., 2008. Sphingoid base levels in humans consuming fumonisin-contaminated maize in rural areas of the former Transkei, South Africa: a cross-sectional study. Food Additives and Contaminants Part A 25: 1385-1391.

Verma, R.J. and Raval, P.J., 1991. Cytotoxicity of aflatoxin on red blood corpuscles. Bulletin of Environmental Contamination and Toxicology 47: 428-432.

Voss, K.A. and Riley, R.T., 2005. Trends in fumonisin research: Recent studies on the developmental effects of fumonisins and Fusarium verticillioides. JSM Mycotoxins 55: 91-100.

Voss, K.A. and Riley, R.T., 2013. Fumonisin toxicity and mechanism of action: overview and current perspectives. Food Safety 1: 2013006.

Voss, K.A., Gelineau-Van Waes, J.B. and Riley, R.T., 2006. Fumonisins: current research trends in developmental toxicology. Mycotoxin Research 22: 61-69.

Voss, K.A., Riley, R.T., Norred, W.P., Bacon, C.W., Meredith, F.I., Howard, P.C., Plattner, R.D., Collins, T.F., Hansen, D.K. and Porter, J.K., 2001. An overview of rodent toxicities: liver and kidney effects of fumonisins and Fusarium moniliforme. Environmental Health Perspectives 109: 259-266.

Warth, B., Sulyok, M., Fruhmann, P., Berthiller, F., Schuhmacher, R., Hametner, C., Adam, G., Fröhlich, J. and Krska, R., 2012a. Assessment of human deoxynivalenol exposure using an LC-MS/ MS based biomarker method. Toxicology Letters 211: 85-90.

Warth, B., Sulyok, M., Fruhmann, P., Mikula, H., Berthiller, F., Schuhmacher, R., Hametner, C., Abia, W.A., Adam, G., Fröhlich, J. and Krska, R., 2012b. Development and validation of a rapid multi-biomarker liquid chromatography/tandem mass spectrometry method to assess human exposure to mycotoxins. Rapid Communications in Mass Spectrometry 26: 1533-1540.

Wells, L., Hardie, L., Williams, C., White, K., Liu, Y., De Santis, B., Debegnach, F., Moretti, G., Greetham, S., Brera, C. and Rigby, A., 2016. Determination of deoxynivalenol in the urine of pregnant women in the UK. Toxins 8: 306.

Wild, C.P. and Gong, Y.Y., 2010. Mycotoxins and human disease: a largely ignored global health issue. Carcinogenesis 31: 71-82.
Wild, C.P. Miller, J.D. and Groopman, J.D. (eds.), 2015. Mycotoxin control in low- and middle-income countries. IARC Working Group Reports 9. IARC, Lyon, France. Available at: http://tinyurl.com/ yazdoe4s.

Wild, C.P., Rasheed, F.N., Jawla, M.F., Hall, A.J., Jansen, L.A. and Montesano, R., 1991. In utero exposure to aflatoxin in West Africa. The Lancet 337: 1602-1605.

Williams, K.C. and Blaney, B.J., 1994. Effect of the mycotoxins, nivalenol and zearalenone, in maize naturally infected with Fusarium graminearum on the performance of growing and pregnant pigs. Australian Journal of Agricultural Research 45: 1265-1279.

Yahia, D. and Kamata, Y., 2017. Cytotoxic activity of fumonisin $B_{1}$ in Vero cells: comparison between 2D and 3D structural microplates. Comparative Clinical Pathology 26: 561-568.

Yamini, B., Bursian, S.J. and Aulerich, R.J., 1997. Pathological effects of dietary zearalenone and/or tamoxifen on female mink reproductive organs. Veterinary and Human Toxicology 39: 74-78.

Yang, J., Wang, Y., Liu, J.L., Fan, J.J. and Cui, S., 2007. Toxic effects of zearalenone and its derivatives $\alpha$-zearalenol on male reproductive system in mice. Reproductive Toxicology 24: 381-387.

Yang, R,, Wang, Y.M., Zhang, L., Zhao, Z.M., Zhao, J. and Peng, S.Q., 2016. Prepubertal exposure to an oestrogenic mycotoxin zearalenone induces central precocious puberty in immature female rats through the mechanism of premature activation of hypothalamic kisspeptinGPR54 signaling. Molecular and Cellular Endocrinology 437: 62-74.

Yazdanpanah, H., Shephard, G.S., Marasas, W.F.O., Van der Westhuizen, L., Rahimian, H., Safavi, S.N., Eskandari, P. and Ghiasian, S.A., 2006. Human dietary exposure to fumonisin $B_{1}$ from Iranian maize harvested during 1998-2000. Mycopathologia 161: 395-401.

Yousef, M.I., Salem, M.H., Kamel, K.I., Hassan, G.A. and El-Nouty, F.D., 2003. Influence of ascorbic acid supplementation on the haematological and clinical biochemistry parameters of male rabbits exposed to aflatoxin $B_{1}$. Journal of Environmental Science and Health Part B 38: 193-209.

Yu, M., Chen, L., Peng, Z., Nüssler, A.K., Wu, Q., Liu, L. and Yang, W., 2017a. Mechanism of deoxynivalenol effects on the reproductive system and fetus malformation: Current status and future challenges. Toxicology In Vitro 41: 150-158.

Yu, M., Chen, L., Peng, Z., Wang, D., Song, Y., Wang, H., Yao, P., Yan, H., Nüssler, A.K., Liu, L. and Yang, W., 2017b. Embryotoxicity caused by DON-induced oxidative stress mediated by NRF2/HO-1 pathway. Toxins 9: 188.

Zacharias, C., van Echten-Deckert, G., Wang, E., Merrill, A.H. Jr. and Sandhoff, K., 1996. The effect of fumonisin $B_{1}$ on developing chick embryos: correlation between de novo sphingolipid biosynthesis and gross morphological changes. Glycoconjugate Journal 13: 167-175.

Zatecka, E., Ded, L., Elzeinova, F., Kubatova, A., Dorosh, A., Margaryan, H., Dostalova, P., Korenkova, V., Hoskova, K. and Peknicova, J., 2014. Effect of zearalenone on reproductive parameters and expression of selected testicular genes in mice. Reproductive Toxicology 45: 20-30.

Zinedine, A., Soriano, J.M., Moltó, J.C. and Manes, J., 2007. Review on the toxicity, occurrence, metabolism, detoxification, regulation and intake of zearalenone: an oestrogenic mycotoxin. Food and Chemical Toxicology 45: 1-18. 
กิ

בे 